Invited Review

\title{
Primaquine revisited six decades after its discovery
}

\author{
Nuno Vale ${ }^{\mathrm{a}}$, Rui Moreira ${ }^{\mathrm{b}}$, Paula Gomes ${ }^{\mathrm{a}, *}$ \\ ${ }^{a}$ Centro de Investigação em Química da Universidade do Porto, Faculdade de Ciências da Universidade do Porto, Rua do Campo Alegre, 4169-007 Porto, Portugal \\ $\mathrm{b}_{i}$ Med-UL, Centro de Estudos de Ciências Farmacêuticas, Faculdade de Farmácia da Universidade de Lisboa, 1600-083 Lisboa, Portugal
}

\section{A R T I C L E I N F O}

\section{Article history:}

Received 21 July 2008

Received in revised form 25 August 2008

Accepted 29 August 2008

Available online 11 September 2008

\section{Keywords:}

8-Aminoquinolines

Gametocytes

Primaquine

Malaria

Plasmodium

\begin{abstract}
A B S T R A C T
Primaquine was firstly synthesized in 1946 in the USA, and is the most representative member of the anti-malarial 8-aminoquinolines. Six decades have passed and primaquine is still the only transmission-blocking anti-malarial clinically available, displaying a marked activity against gametocytes of all species of human malaria, including multi-resistant Plasmodium falciparum strains. Primaquine is also effective against all exoerythrocytic forms of the parasite and is used in conjunction with other anti-malarials for the treatment of vivax and ovale malaria. However, primaquine is often associated with serious adverse effects, in consequence of its toxic metabolites. 5-Hydroxyprimaquine or 6methoxy-8-aminoquinoline has been considered to be directly responsible for complications such as hemolytic anemia. Primaquine toxicity is aggravated in people deficient of 6-glucose phosphate dehydrogenase or glutathione synthetase. Adverse effects are further amplified by the fact that primaquine must be repeatedly administered at high doses, due to its limited oral bioavailability. Over the last two decades, Medicinal Chemists have battled against primaquine's disadvantages, while keeping or even improving its unequalled performance as an anti-malarial. The present text revisits primaquine and its properties on the occasion of its 60th anniversary and aims to give a general overview of what has been the path towards the development of effective and safe primaquine-based anti-malarials. Presently, aablaquine and tafenoquine the two most promising primaquine analogues are already in the final stages of clinical trials against Plasmodium vivax and P. falciparum. Both compounds are a new hope against malaria and other primaquine-sensitive illnesses, such as Pneumocystis Pneumonia or the Chagas disease.
\end{abstract}

(c) 2008 Elsevier Masson SAS. All rights reserved.

\section{Primaquine revisited}

\subsection{Historical synopsis}

Tropical diseases, normally confined to underdeveloped regions of the globe, have been traditionally neglected by the pharmaceutical industries and, consequently, seldom considered as hot matter capable of drawing the attention of top scientists, from chemists to physicians. This attitude was changed by force of historical events in some periods, such as the first half of the 20th century, when world-wide belligerency required western soldiers, fighting in tropical regions, to be protected against this epidemics $[1,2]$. Consequently, in the 30 years' gap between the middle of World War I and the end of World War II was examined a huge

\footnotetext{
* Corresponding author. Tel.: +351 220402563; fax: +351 220402659.

E-mail address: pgomes@fc.up.pt (P. Gomes).
}

number of potential anti-malarial drugs, over 12000 of which were 8 -aminoquinolines (8AQ) [3]. One of the first anti-malarial $8 A Q s$, known as pamaquine or plasmochin $(\mathbf{1})$, was synthesised in 1925 and was able to destroy the parasite's gametocytes when used in combination with quinine. This was useful for the prevention of relapses associated to the Plasmodium vivax infection [4], but pamaquine showed little effectiveness against bloodinduced infection, i.e., it was a poor blood-schizontocide. But the greatest disadvantage of this drug was its high toxicity that ultimately led to the abandonment of its therapeutic use [5]. Notwithstanding, pamaquine represented the stepping-stone for the development of safer anti-malarial 8AQs that culminated, in 1946, in the synthesis of the 8AQ SN-13,272 by Elderfield and coworkers, in the United States of America [6]. This compound, named primaquine (PQ 2), was successfully tested in WWII prisoners, American volunteers and American soldiers fighting in regions like Korea [6]. Other anti-malarial 8AQs, such as pentaquine or isopentaquine [7-9], also appeared in the 1940s, but PQ was the one presenting the highest efficacy and the lowest toxicity levels. 

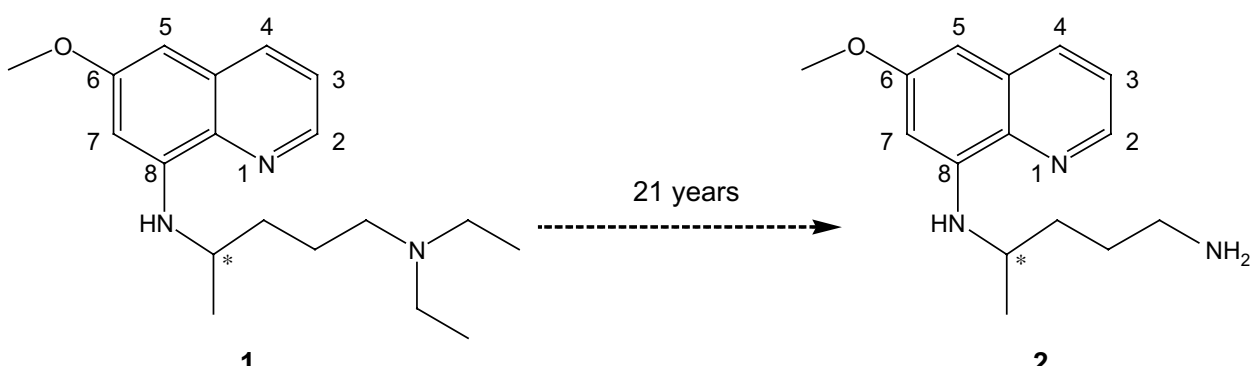

1

2

By the end of WWII, strategies for malaria treatment passed by the employment of $\mathrm{PQ}$ primarily as a transmission-blocking antimalarial (gametocytocide) but also as a tissue-schizontocide, as well as of chloroquine (CQ), a potent blood-schizontocidal 4-aminoquinoline (4AQ), also effective against the most lethal Plasmodium falciparum strains [10]. This, and the use of DDT against the mosquito vectors, led to the eradication of malaria from tempered and sub-tropical regions of the globe by the early 1960s, which cooled the interest of developed countries in continuing the search for improved anti-malarials, even though some problems associated with current therapies were already being identified in endemic areas like Sub-Saharan Africa [10]. Some of these problems included the aggravated hematotoxicity of PQ in humans deficient in 6-glucose phosphate dehydrogenase (6GPD), a genetic condition frequent among African men, and the development of general resistance of $P$. falciparum against CQ [10]. Again, these problems were mainly restricted to tropical countries and did not captivate the interest of either the western pharmaceutical industry or the scientific community until the 1980 s, when some cases of malaria were registered in sub-tropical and tempered areas [11] "Imported malaria" is presently a serious risk world-wide due to both increased people's migration or tourism-related mobility and global warming. It is a top-priority disease and composes the WHOs "big-three" together with tuberculosis and AIDS [11]. This sprang a new search for more active and safer anti-malarials over the last two decades, much of it inspired in PQ and related 8-aminoquinolines [12,13].

\subsection{A snapshot of PQ's therapeutic profile}

\subsubsection{Against malaria: use, limitations and search for alternative administration strategies}

PQ is useful to fight malaria on three different fronts: (i) primary prophylaxis against all species of malaria, (ii) presumptive antirelapse therapy (terminal prophylaxis) for persons extensively exposed to P. vivax or Plasmodium ovale, (iii) radical cure in individuals infected with $P$. vivax or $P$. ovale [14]. In endemic regions, PQ is used as a gametocytocide to prevent the transmission of the infection from the human host to the mosquitoes, thus blocking the spread of the disease [15].

Normally, a total of $200 \mathrm{mg}$ dose of PQ (as the free base $\approx 350 \mathrm{mg}$ of the phosphate salt) leads to a full cure. The regimen usually adopted and generally well-tolerated is $15 \mathrm{mg}$ per day over 14 days [9,14]. Table 1 summarises the different PQ-based therapeutic approaches, according to the acuteness of the infection. PQ is contraindicated for children under 4 years old and its administration requires a previous test for glucose-6-phosphate activity (G6PD) in the patient [16]. PQ is not suitable to be used as a single drug to treat malaria, as it is not effective against endoerythrocytic forms of Plasmodia, thus must be co-administered with blood-schizontocides [9].

The reappearance of malaria vivax in certain regions of the world by the end of the 20th century reinforced the relevance and the need of finding more effective treatments for the disease. An inadequate attack on the hypnozoite reservoir of infection can contribute to the aggravation of malaria. Ideally, PQ should be a well-tolerated drug and a totally safe drug of easy administration, so it could be employed at higher doses without risk for the patient (cf. Section 2). However, further from the aforementioned problems related to PQ-based therapies, PQ is not prescribed during pregnancy because of the risk of intravascular hemolysis in the mother and fetus [17]. Recently, changes in the platelet count and lipid parameters are reported for malarial patients after treatment with hydroxychloroquine and PQ for acute $P$. vivax malaria [18].

To circumvent problems associated with $\mathrm{PQ}$, some researchers have proposed high-dosages over short administration periods, whereas others have recommended the use of quinine while assessing the efficacy of PQ at either standard or experimental PQ

Table 1

PQ-based therapeutic approaches against vivax and ovale malarias

\begin{tabular}{|c|c|}
\hline \multicolumn{2}{|c|}{ Therapeutic approach Description } \\
\hline Primary prophylaxis & $\begin{array}{l}\text { Prevents primary installation of parasitemia, in } \\
\text { opposition to terminal prophylaxis that prevents } \\
\text { relapse (see below). } \\
\text { A daily } 30 \mathrm{mg} \text { dose (adult) is used and the } \\
\text { administration begins one day before the risk of } \\
\text { exposition, i.e., arrival to a malaria-endemic region, } \\
\text { and is prolonged for } 1 \text { week after departure from that } \\
\text { region. For children and adults under } 60 \mathrm{~kg} \text { of weight, } \\
\text { the recommended dose is } 0.5 \mathrm{mg} / \mathrm{kg} / \mathrm{d}[14] \text {. }\end{array}$ \\
\hline $\begin{array}{l}\text { Terminal prophylaxis } \\
\text { or PART }\end{array}$ & $\begin{array}{l}\text { Presumptive anti-relapse therapy (or terminal prophy- } \\
\text { laxis) uses medications towards the end of the exposure } \\
\text { period (or immediately thereafter) to prevent relapses } \\
\text { or delayed-onset clinical presentations of malaria } \\
\text { caused by hypnozoites (dormant liver stages) of } P \text {. vivax } \\
\text { or } P \text {. ovale [14]. } \\
\text { PQ is used in conjugation with a schizontocide } \\
\text { (chloroquine, mefloquine, doxycycline) at a recom- } \\
\text { mended daily dose of } 15 \text { mg PQ during } 14 \text { days } \\
\text { (adults). However, full elimination of hypnozoites of } \\
\text { some } P \text {. vivax strains requires an increase of the daily } \\
\text { dose to } 30 \text { mg. Similarly, the paediatric doses can be } \\
\text { increased from } 0.25 \text { to } 0.5 \text { mg/kg/d, according to the } \\
\text { parasite strain that prevails at the site of exposure. The } \\
\text { beginning of terminal prophylaxis with PQ should } \\
\text { coincide with the last } 2 \text { weeks of prophylactic admin- } \\
\text { istration of schizontoxides doxycycline, mefloquine or } \\
\text { chloroquine or with the final week of prophylaxis with } \\
\text { atovaquone-proguanil [ } 14,19,20 \text { ]. }\end{array}$ \\
\hline Radical cure & $\begin{array}{l}\text { PQ is administered together with a blood-schizontocide } \\
\text { (e.g., chloroquine) for complete cure of installed } P \text {. vivax } \\
\text { and } P \text {. ovale infections with the advantage that PQ can } \\
\text { prevent relapses due to hypnozoites of both strains, as } \\
\text { described above. Recommended PQ dosage is the same } \\
\text { as described for terminal prophylaxis [14,21-23]. }\end{array}$ \\
\hline
\end{tabular}


regimens [24]. Yet, PQ at high doses may affect gene expression in liver and may produce undesirable outcomes if administered over long time periods [25].

PQ is also characterized by low plasma half-lives, which require frequent administration and amplify its adverse effects (cf. Section 2 ). To reduce these effects and increase the efficacy of treatment, some researchers have suggested different routes of PQ administration, such as transdermal therapeutic systems (TTS), encapsulation in nanoparticles or liposomes, and emulsification.

One example of the TTS approach is the work by Mayorga et al. who established an ethyl cellulose-based TTS formulation that was shown to be viable and bring advantages for transdermal delivery of PQ [26]. Thus, PQ presented high flow in vitro from a Miglyol 840 (M840) TTS across hairless rat skin; recent studies indicated extensive binding to corneocyte keratin with significant effect on reservoir formation and on the permeability of PQ across human skin [27].

Galactose-coated polypropyleneimine (PPI) nanoparticles were tested as PQ vehicles and were found to have drug entrapment efficiency 5-15 times higher than that of uncoated PPI. Galactose coating prolonged release up to 5-6 days as compared to 1-2 days for uncoated PPI systems [28]. PQ has also been conjugated to periodate-oxidized Gum Arabic through the drug's amino groups, which allowed obtaining microspheres too small to be attacked by macrophages $[29,30]$.

Nebulization of an aqueous mixture of PQ diphosphate and albumin into heated vegetable oil was used to produce microspheres with an average size of $6 \mathrm{~mm}$. These microparticles were relatively stable in buffer at $\mathrm{pH} 7.2$ and 4.5 , while being completely degraded by proteolytic enzymes such as trypsin. Pharmacokinetic studies suggested the microparticles to accumulate in liver showing sustained release of PQ for at least $48 \mathrm{~h}$ post-administration [31].

The preparation of PQ-loaded-poly (D,L-lactide) nanoparticles was reported as well. Intravenously injected PQ-loaded nanoparticles were well-tolerated by healthy and Leishmania donovani-infected mice. The $50 \%$ lethal dose of primaquine-loaded nanoparticles was significantly reduced when compared to that of free PQ [32].

PQ was also incorporated into oral lipid nanoemulsions having particle sizes in the range of $10-200 \mathrm{~nm}$. The emulsions showed effective anti-malarial activity against Plasmodium berghei infection in Swiss albino mice at $25 \%$ lower dose levels as compared to the conventional oral dose. Lipid nanoemulsions of $\mathrm{PQ}$ exhibited improved oral bioavailability and were taken up preferentially by the liver with drug concentrations higher at least by $45 \%$ as compared to the plain drug [33].

PQ has been successfully encapsulated in liposomes in response to a $\mathrm{pH}$ gradient. The efficacy of PQ encapsulation depended on the lipids that composed the vesicles and, consequently, on liposome charge and presence of cholesterol, on the buffer internal capacity and on the drug-to-lipid ratio and/or incubation time [34].

Finally, additional studies where $\mathrm{PQ}$ was incorporated in emulsions have shown the drug to be more stable when emulsified than when given as the free compound incubated in serum. When intravenously injected into mice, the chylomicron emulsions containing PQ led to an increased accumulation of PQ in liver, as compared to injection of free PQ [35].

Notwithstanding, none of the above alternative routes for PQ administration have stepped forward to clinical applications.

\subsubsection{Against pneumocystic pneumonia}

Pneumocystis jiroveci is a fungus that contacts innocuously with healthy lungs, but causes pneumocystic pneumonia (PCP) in individuals with weakened immune systems, such as patients with cancer or under anti-cancer treatments, patients submitted to organ transplantation or HIV-infected individuals. PCP is often the first indicator of HIV-infection and over $80 \%$ of patients with AIDS that have not received a buffer prophylaxis end up developing PCP at any moment, which leads to a fast degradation of their health condition and quality of life and, ultimately, to death [36-39].

PQ is useful against PCP, both for prophylaxis and for treatment, when given in combination with clindamycin (CM, 3). PQ interferes with the microbial electron transport system by yielding quinone metabolites that generate superoxides in vivo [40]. The PQ-CM approach is employed for the treatment of moderate PCP or as salvage therapy [42-49]. The effective daily dose for PCP treatment is $2 \mathrm{mg} / \mathrm{kg}$ of PQ and $225 \mathrm{mg} / \mathrm{kg}$ of CM. Lower doses are applied for prophylaxis [40].

So far, the first-line therapy against PCP is the trimethoprimsulfamethoxazole antifolate combination found in Bactrim ${ }^{\mathrm{TM}}$ or Septra ${ }^{\circledR}$. However, there is a high frequency of development of severe intolerance to the sulfa component among patients with AIDS [48]. This justifies the need for alternative therapies such as $\mathrm{PQ}-\mathrm{CM}$, even though this approach has itself some complications due to PQ-associated toxicity, the main of which is anemia [44]. Therefore, other PQ analogues or derivatives have been explored as anti-PCP agents $[43,45,46]$.

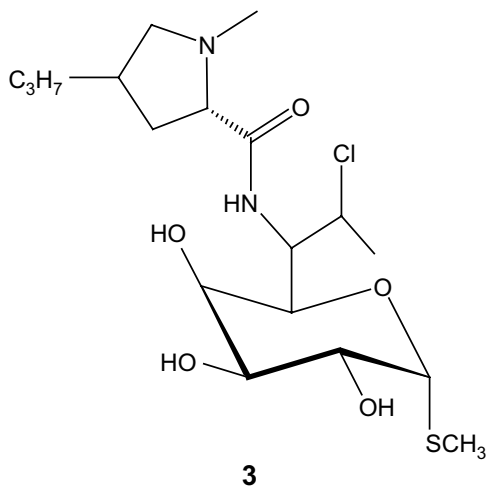

\subsubsection{Against leishmaniasis}

Leishmaniasis affects mostly canines but can be transmitted to humans. It is caused by different species of a protozoan belonging to the Leishmania genus. Humans are mainly affected by three forms of Leishmania: Leishmania cutanea, Leishmania mucocutanea and Leishmania visceral. Typically, patients with visceral leishmaniasis present fever, cough, abdominal pain, diarrhoea, epistaxis, spleenomegaly, hematomegaly, cachexia and pancytopenia [49].

Even though PQ has no clinical application against leishmaniasis, it exhibits leishmanicidal activity in vitro [50]. Some derivatives of $\mathrm{PQ}$ especially 6-desmethyl-8-aminoquinolines, have been generally more active in vitro than the parent drug against macrophage-contained Leishmania [50]. Recently, Kaur et al. presented several biological studies focused on 8AQs and confirmed that $\mathrm{PQ}$ has leishmanicidal activity in vitro, but with $\mathrm{IC}_{50}$ values $(\sim 20 \mu \mathrm{g} / \mathrm{mL})$ superior to those of reference drugs in leishmaniasis therapy, such as pentamidine ( $\mathrm{IC}_{50}=1 \mu \mathrm{g} / \mathrm{mL}$ ) or amphotericin B ( $\mathrm{IC}_{50}=0.19 \mu \mathrm{g} / \mathrm{mL}$ ) [51]. PQ also showed in vitro leishmanicidal properties when encapsulated in liposomes, against parasiteinfected macrophages [52].

Despite the lack of prominence of PQ in this therapeutic area, many related $8 \mathrm{AQs}$ are exhibiting promising results. The relevant examples are those of two anti-malarial compounds, NPC 1161 [53] and, especially, sitamaquine that is already in an advanced phase of clinical trials (see Section 4.3) [54-56]. 


\subsubsection{Against trypanosomiasis}

Chagas disease (American trypanosomiasis) is a zoonosis caused by the flagellate protozoan parasite Trypanosoma cruzi and affects approximately 18 million people in Central and South America [57].

PQ is not clinically used for the therapy of Chagas disease. However, both PQ and its 2-methyl-PQ derivative were reported to be almost four times as effective as the control drug, nifurtimox, against the model disease in mice [58]. One of the hypotheses that advanced for the anti-trypanosomiasis activity of PQ and related $8 \mathrm{AQs}$ relies on the metabolic formation of free radicals that increase the oxidative stress in T. cruzi [59].

Experiments were designed to evaluate the relative activity of PQ against extra- and intracellular $T$. cruzi and to determine whether this drug should be combined with ketoconazole (4), an antifungal imidazole and potent CYP3A4 inhibitor [60]. The combination of $\mathrm{PQ}$ with ketoconazole, administered to acutely infected mice, significantly decreased parasitemias in comparison to treatment with PQ or ketoconazole alone [61].

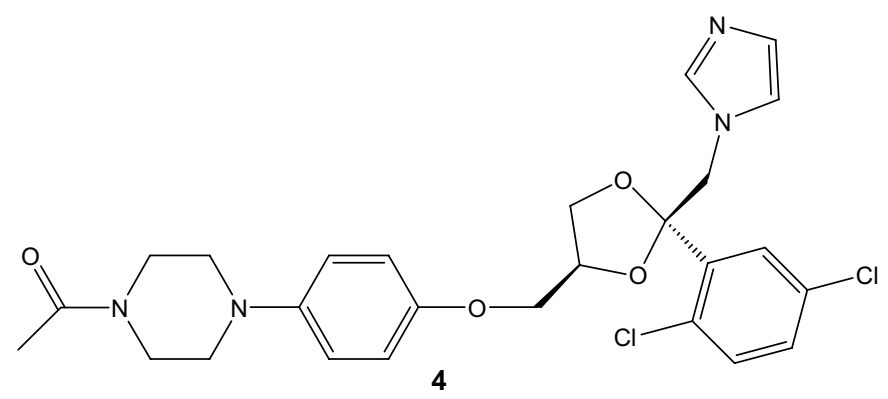

\subsubsection{Against other diseases}

PQ and related drugs have seldom been studied as potentially useful against diseases other than those above indicated. However, some isolated reports can be found, such as the study, in 1974, of the effect of PQ against viral replication in Newcastle disease. This study was carried out in chicken embryo cells and showed that virus-induced hemadsorption was completely inhibited by $250 \mu \mathrm{g}$ of $\mathrm{PQ} / \mathrm{mL}[62]$.

Also, a series of experiments were conducted to investigate the anticoccidial activity of pamaquine and $\mathrm{PQ}$ against laboratory strains of Eimeria tenella, Eimeria necatrix, Eimeria acervulina, Eimeria maxima and Eimeria brunette, revealing that both drugs were effective against $E$. tenella and $E$. necatrix, but not against the other three species [63]. The anticoccidial activity of PQ has also been tested by Armer et al. who found that both PQ and pamaquine possess in vivo anticoccidial activity in broilers against the protozoan parasites E. tenella and E. necatrix [64,65]. These authors established that the drugs are not active themselves against Eimeria, but generate active metabolites in vivo, thus actuating as prodrugs.

\subsection{PQ combined with other drugs}

There are several arguments for the use of combinations of drugs for the treatment of disease, the main of which is based on simultaneous attack to different biological targets that are vital to the pathogen [66]. PQ-based therapies are no exception.

The combination of PQ with chloroquine (CQ) was used in the Korea War (1950-1953) by American soldiers infected with relapsing $P$. vivax malaria. This combination was commercialized in tablets under the name of ' $\mathrm{CP}$ '. Each tablet contained $300 \mathrm{mg}$ of $\mathrm{CQ}$ and $45 \mathrm{mg}$ of $\mathrm{PQ}$ and was administered following repatriation once weekly for 8 consecutive weeks. 'CP' was abandoned when parasite's, especially $P$. falciparum's, resistance to CQ was detected in the 1960's. Notwithstanding, CQ + PQ combinations have a role against both tissue and blood-schizontocides that are to be deployed in endemic areas [67]. CQ sulfadoxine/pyrimethamine and PQ were combined together in an early work, and while no effect on asexual stage parasitemia was apparent, clearance of gametocytes was significantly accelerated [68]. Bray et al. analysed matched transfectants expressing mutant and wild-type alleles of the P. falciparum chloroquine resistance transporter (PfCRT) and concluded that PQ exerts its activity by blocking PfCRT, thus enhancing accumulation of CQ [69]. Moreover, the alternative administration of PQ and CQ sequentially instead of simultaneously is clinically viable, and may constitute a cost-effective way of treating CQ-resistant malaria [70].

Co-administration of mirincamycin $(2.5 \mathrm{mg} / \mathrm{kg})$ with $\mathrm{PQ}$ was seen to exert a significant reduction in the dose of $P Q$ required for cure of established infections with sporozoites of Plasmodium cynomolgi. This effect was further seen to be inversely related to the size of the sporozoite inoculum [71].

Quinine has no significant effect on the kinetics of PQ but a decrease in $C_{\max }$ of carboxyprimaquine was observed after coadministration with quinine. The interaction of $P Q$ with mefloquine was also investigated in human liver microsomes and it appeared that metabolism of mefloquine was somewhat retarded by $\mathrm{PQ}$. However, co-administration of PQ did not affect the pharmacokinetics of mefloquine in vivo. On the other hand, in vitro studies have shown that $\mathrm{PQ}$ conversion into carboxyprimaquine is inhibited by ketoconazole (4) [72].

Last, but not least, PQ combinations with artemisinin derivatives also seem interesting. Artesunate reduced the appearance of gametocytemia in adult Thai patients infected with uncomplicated P. falciparum malaria, whereas its combination with PQ resulted in shorter gametocyte clearance times [73]. In other study, the combination of 5 days of artesunate and 14 days of PQ was found to be a highly effective and generally well-tolerated treatment regimen for vivax malaria in Thailand [74].

\subsection{Primaquine in the body}

\subsubsection{A yet unveiled mechanism of action}

The exact mechanism by which PQ so effectively eliminates Plasmodia hypnozoites and gametocytes is still unknown, but it is thought that metabolism at the parasites' mitochondria is impaired, eventually by interference with the ubiquinone function as an electron carrier in the respiratory chain [75]. Another potential mechanism of anti-malarial action by PQ is the production of highly reactive metabolites (cf. Section 2) that generate intracellular oxidative potentials [14]. Biotransformation of 8AQ seems to be necessary for their toxicity as well as efficacy. Selective generation of oxidative stress in the parasitized cells is the most plausible mechanism for 8AQ toxicity and efficacy [76].

While the mechanism of action of $4 A Q$ (as chloroquine) is believed to be based on detoxification of hematin in the parasite's food vacuole (FV) that of $8 \mathrm{AQs}$ remain unclear. When the $4 \mathrm{AQ}$ drug reaches the proton-rich $\mathrm{FV}$, it accumulates due to the local $\mathrm{pH}$; there it binds to hematin, whose accumulation in the FV leads to the death of the parasite [10,77-80]. In turn, how and why PQ and related $8 A Q s$ specifically act against certain stages of the parasite's life cycle is still a matter of debate. During the third morphological stage of $P$. falciparum gametocyte formation (Fig. 1), macrogametocytes begin to show a marked increase in cristate mitochondria [81]. Normally, late-stage gametocytes (stages IV-V in Fig. 1) are more resistant to anti-malarial drugs [82] and metabolic inhibitors [83] than are early-stage gametocytes or asexual forms of the parasite. PQ is the one drug to which the late-stage gametocytes are more sensitive than asexual stages. Selective accumulation of tritiated PQ ( $\left.{ }^{3} \mathrm{H}-\mathrm{PQ}\right)$ in Plasmodium mitochondria was seen to 


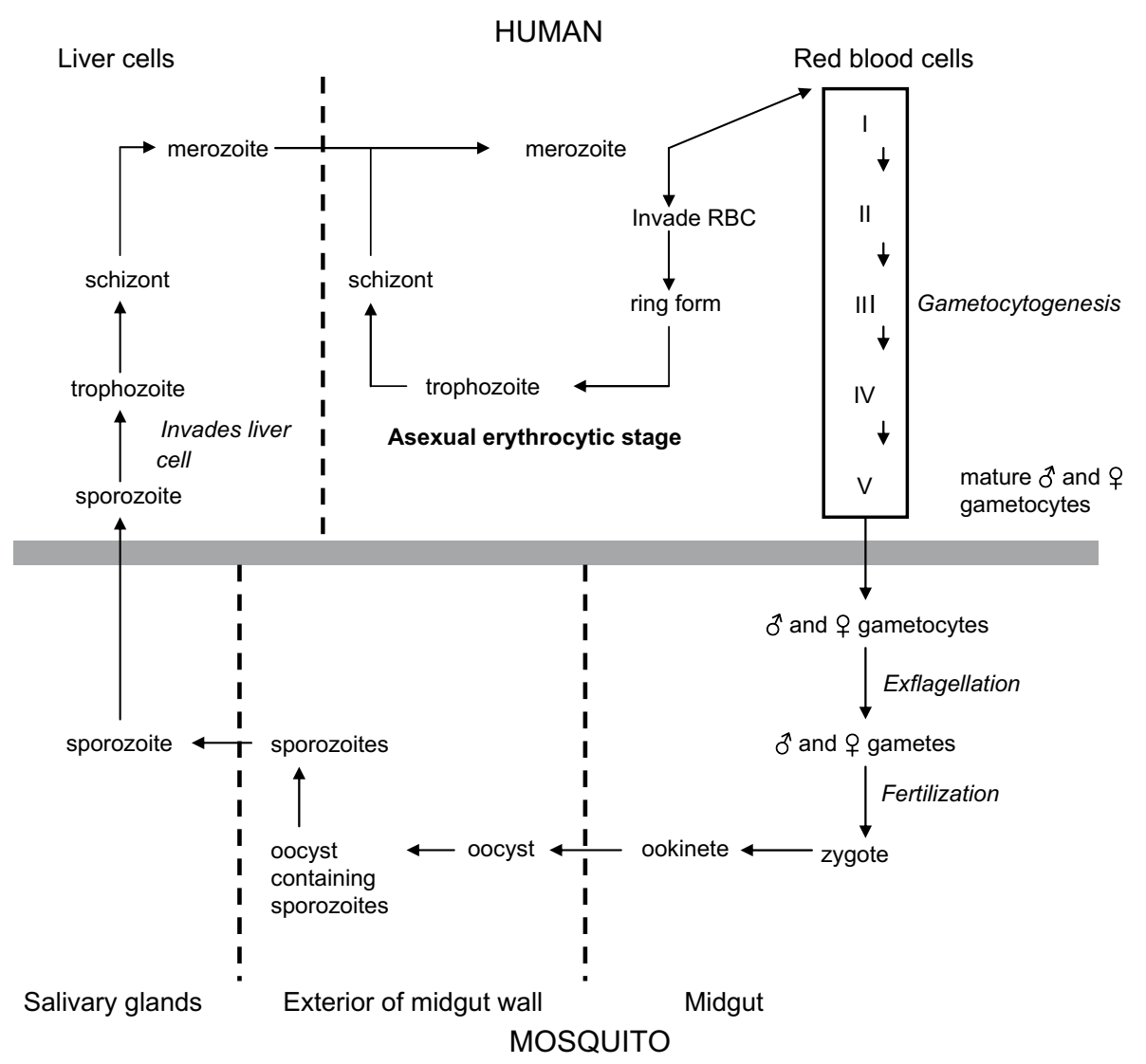

Fig. 1. The life cycle of Plasmodium falciparum. Adapted from Ref. [83].

coincide with the appearance of mitochondrial swelling in the tissue stages of Plasmodium fallax [84]. Other studies indicate that it causes mitochondrial swelling in several Plasmodium strains and stages [85-87], including P. falciparum gametocytes [88]. Additional reports suggest that exposure to $P Q$ affects mitochondrial proliferation and inhibits growth on development stages that require functional mitochondria [87,89-93].

Irrespective of the specific underlying biochemical mechanisms, it is undeniable that metabolically senescent stages of Plasmodia are sensitive to 8AQs. Evidence of mitochondrial ultrastructure changes in $P$. falciparum when exposed to 8AQs reinforces that these may be related to the biochemical changes in the mitochondria-directed metabolic activity of the parasite [81]. Alternatively, the lack of biochemical mechanisms in the parasite suitable to eliminate PQ or its metabolites, as well as stage-specific inability to cope with oxidative stress, may account for both the low parasitic resistance against $P Q$ and its specificity against certain stages of the parasite's life cycle [94].

Bapiro and co-workers investigated the inductive effects of 24 antiparasitic drugs on the enzymatic activity of cytochromes $\mathrm{P}_{450}$ (CYP) 1A1 and 1A2 [95]. These authors used human hepatoma (HepG2) cells that were exposed to the test drugs, after which the ethoxyresorufin-O-deethylase (EROD) activity was evaluated as a measure of CYP1A enzyme activity. In the human body, PQ did not cause a significant induction at concentrations typically found in plasma $(\sim 0.4 \mu \mathrm{M})$ and the authors concluded that induction of CYP1A1/2 activity by PQ was not of any pharmaceutical or toxicological significance [95].

Studies in vitro by Olenick and Hahn with Bacillus megaterium suggested that the main route by which PQ acts against this bacterium is by the blockage of protein synthesis [96]. The same authors reported 3 years later that $\mathrm{PQ}$ inhibited polyphenylalanine synthesis directed by poly(U) in cell-free systems obtained from $B$. megaterium, when the drug was pre-incubated with ribosomes, poly(U) or ${ }^{\mathrm{R} N A}$ [97]. However, so far there is no evidence that impairing of plasmodial protein synthesis lies behind the antimalarial action of $P Q$.

As PQ has a stereogenic centre, it would be expectable that each isomer had different activities, considering the most probable involvement of enzymes in the drug's mechanism of action. Many scientists defended that PQ isomers have similar activity, based on the fact that both presented identical capacity for the radical cure of rhesus monkeys infected with sporozoites of $P$. cynomolgi [98]. Studies in mice indicated that the subacute toxicity of $l-\mathrm{PQ}$ is $3-5$ times higher than that of $d-\mathrm{PQ}$ and 2 times less than PQ. The acute single-dose toxicity of the $d$-PQ was at least 4 times as toxic as $l-\mathrm{PQ}[98,99]$. It is noteworthy that PQ is not a racemic mixture, because $l$ isomer prevails over the $d$ isomers. When racemic $\mathrm{PQ}$ was administered to rats, the majority of the residual PQ excreted in urine was found to be the (+)-isomer [100]. Agarwal et al. studied in vitro the effects of $\mathrm{PQ}$ enantiomers and observed that a $1.5 \mathrm{mM}$ concentration of (-)-PQ produced a significantly greater increase in methemoglobinemia (MetHb) content and decrease in reduced glutathione (GSH) levels than did (+)-PQ. However, the release of plasma hemoglobin was greater with (+)-PQ than with (-)-PQ [101]. On the whole, it is clear that PQ biotransformations behind both its toxicity and its anti-malarial action involve chiral recognition, even though exact mechanisms are not yet established.

The in vivo skin absorption profile of PQ was also investigated through employment of a TTS based on ethyl cellulose polymer, indicating controlled and systemic delivery of the drug over a period of $40 \mathrm{~h} \mathrm{[102]}$. The permeation of PQ across full-thickness excised human skin from two acrylate transdermal adhesives was 
also studied, suggesting that a relatively simple transdermal adhesive patch formulation incorporating PQ can deliver suitable doses to provide new treatment and prophylaxis regimens for $P$. vivax and $P$. ovale malaria [103].

\subsubsection{Other biological effects of $P Q$}

PQ was found to be an inhibitor of vesicular transport and blocks the calcium-release-activated current $\left(I_{\text {crac }}\right)$ in rat megakaryocytes, i.e., PQ blocks the appearance of $\mathrm{Ca}^{2+}$ influx currents in response to $\mathrm{Ca}^{2+}$ store depletion in rat. PQ is less effective if added after $I_{\text {crac }}$ had developed. The channels underlying $I_{\text {crac }}$ may be held in a membrane compartment and transport to the plasma membrane follows release of internal $\mathrm{Ca}^{2+}[104]$. The role of membrane fusion in the activation of store-activated $\mathrm{Ca}^{2+}$ channels (SACCs) in plasma membrane of oocytes in Xenopus laevis was investigated in the presence of PQ. The results indicate that PQ affects the opening of SACCs by direct inhibition of $\mathrm{Ca}^{2+}$ flux through the channel pores [105].

PQ also acts on cardiac $\mathrm{Na}^{+}$channels, according to another research work where the electrophysiological effects of PQ on those channels were examined in isolated rat ventricular muscle and myocytes. PQ was found to block the cardiac channels with high affinity, exhibiting high selectivity for the $\mathrm{Na}^{+}$channel blockade in comparison to the blockade of the $\mathrm{K}^{+}$cardiac channel [106].

Protein transport is affected by PQ at a half-maximal concentration of $50 \mu \mathrm{M}$ and morphological data indicate that the drug inhibits the budding of vesicles from the donor membranes. After their formation, the vesicles are refractive to PQ action, so their attachment and subsequent fusion with an acceptor membrane proceed normally [107]. Also, insertion of pre-formed fibrosis transmembrane conductance regulator (CFTR) into the plasma membrane could be prevented by compounds that interfere with intracellular transport mechanisms such as PQ [108].

The weakly basic character of PQ leads to its accumulation in endosomes in its protonated form and, consequently, it modifies the endosomal $\mathrm{pH}$. Further, PQ has a strong inhibitory effect on the recycling of endocytosed proteins to the plasma membrane [109]. This inhibitory effect of PQ may be due to the interference with calmodulin function at endosomes. PQ inhibited $\mathrm{Ca}^{2+} /$ calmodulindependent kinase II (CaM-kinase II) activity with maximal inhibition at $1 \mathrm{mM}$, consistent with the idea that the crucial factor behind PQ interference with membrane protein recycling could be modification of calmodulin activity [110].

Several anti-malarial agents inhibit diverse types of voltagegated ionic channels [111-113], as well as acetylcholine (Ach) receptors that operate in potassium current ( $\left.I_{\mathrm{KAch}}\right)$ through muscarinic potassium channels, alone or linked to GTP-proteins (guanosine-5'-triphosphate-linked proteins) [111]. Distinct anti-malarials may exhibit anticholinergic activity via different molecular mechanisms; PQ and quinidine inhibit the potassium current by blockade of muscarinic receptors [111]. In an early study, the capacity of some anti-malarials, including $\mathrm{PQ}$ to inhibit human erythrocyte membrane acetylcholinesterase (AChE) and the mechanism underlying their inhibitory action were evaluated [114]. This study revealed that all tested drugs were potent inhibitors of human AChE but had distinct inhibitory capacities. In the case of $\mathrm{PQ}$ the concentration requested to obtain $33 \%$ of inhibition $\left(\mathrm{IC}_{33}\right.$ ) was $30 \mu \mathrm{M}$ [114].

Michihara et al. reported the effects of PQ on lysosomal integrity in cultured rat hepatocytes and the percentage of lysosomal disruption in living cells at $50 \mu \mathrm{M}$ and $100 \mu \mathrm{M}$ of drug to be $1 \%$ and $4 \%$, respectively. Additionally, levels of lysosomal disruption upon homogenization or centrifugation during cell fraction at those two concentrations of PQ were $2 \%$ and $7 \%$, respectively [115].

Finally, the mutagenic activity and mutational specificity of PQ were studied after pre-treatment with nitrite on Escherichia coli and Salmonella typhimurium. The drug was mutagenic in both microbial strains, suggesting that PQ is a nitrite-reacting mutagen precursor where the secondary amino group plays a key role [116].

\section{Drawbacks in PQ-based therapies}

\subsection{Parasitic resistance}

The establishment that parasitic resistance is occurring requires the demonstration that parasites are able to survive in vivo in the presence of an adequate therapeutic concentration of the drug system [117]. Several anti-malarial drugs are referenced as affected by the problem of resistance by Plasmodia, among which chloroquine is known to present severe resistance problems from both the deadliest $P$. falciparum and the second most concerning $P$. vivax strains [118-120].

The resistance to PQ is incredibly low, hardly noteworthy, fact which is not still very well understood. Some have argued that this phenomenon may arise from an association of physical, chemical or biological properties of the drug, together with its low half-life or ability to sterilise the parasite's gametocytes [9]. Since 1961, PQ is known to elicit some resistance from asexual blood stages of $P$. vivax, but such is of no clinical consequence [20]. Some clinical evidences of $\mathrm{PQ}$ resistance are occasionally reported, but their detection is rare. In the last two decades, some accounts concerning relapses of vivax malaria shortly after PQ therapy were registered essentially in the Western Pacific, Southeast Asia, India, Central and South America [121]. Notwithstanding, the frequency, intensity and distribution of those isolated registers do not seem alarming.

\subsection{Methemoglobinemia}

One of the most relevant adverse effects of $\mathrm{PQ}$ and of other 8AQs, is methemoglobinemia. This is a pathological condition arising from abnormal accumulation of methemoglobin (MetHgb), the auto-oxidation product of the hemoglobin iron core.

Oxyhemoglobin, $\mathrm{Hgb}(\mathrm{Fe}(\mathrm{II})) \mathrm{O}_{2}$ is a very stable molecule that undergoes slow auto-oxidation at a daily rate of about $3 \%$. The oxidation generates methemoglobin, MetHb [or $\mathrm{Hgb}(\mathrm{Fe}(\mathrm{III}))$ ], and the superoxide radical [122]. The superoxide undergoes dismutation to oxygen and hydrogen peroxide, which is rapidly decomposed by catalase but some of it reacts with $\mathrm{Hgb}(\mathrm{Fe}(\mathrm{II})) \mathrm{O}_{2}$ to produce ferrylhemoglobin, $\mathrm{Hgb}(\mathrm{Fe}(\mathrm{IV}))=\mathrm{O}$ that bears a rhombic heme and is difficult to find in vivo since it is rapidly transformed into $\mathrm{Hgb}(\mathrm{Fe}(\mathrm{III})) \mathrm{O}_{2}$ upon further reaction with $\mathrm{Hgb}(\mathrm{Fe}(\mathrm{II})) \mathrm{O}_{2}$.

The formation of $\mathrm{Fe}^{3+}$-methemoglobin is favoured under adverse situations such as oxidative stress, infection, glucose-6-phosphate dehydrogenase deficiency or influence of xenobiotics. This leads to an increase of MetHb concentration in the body, which implies a high health risk, such as (i) $\mathrm{O}_{2}$ cannot bind the oxidised iron of the MetHb heme, thus MetHb cannot transport $\mathrm{O}_{2}$ to the different tissues; (ii) when one or more subunits have their heme iron oxidised or attached to $\mathrm{CO}$, the protein quaternary structure is changed and the affinity of the remaining non-oxidised heme groups towards $\mathrm{O}_{2}$ is increased, implying a less favoured dissociation of $\mathrm{O}_{2}$ from the heme groups, thus also compromising oxygen delivery to tissues [123].

Practically almost all 8AQs, including PQ and several of its metabolites, induce MetHb formation at a rate and extension higher than usual [124]. Methemoglobinemia usually occurs with therapeutic or prophylactic dosing regimens. Cyanosis can occur when the MetHb level exceeds $15-20 \mathrm{~g} / \mathrm{L}$ in the blood ( $\sim 10 \%$ of the normal hemoglobin level), although cyanosis may be seen in fairskinned persons at MetHb levels below 6\% [14]. Additionally, persons who are deficient of the enzyme NADH methemoglobin reductase are extremely sensitive to hemoglobin-oxidizing drugs such as PQ. Fortunately, this enzymatic deficiency is rare [14]. 


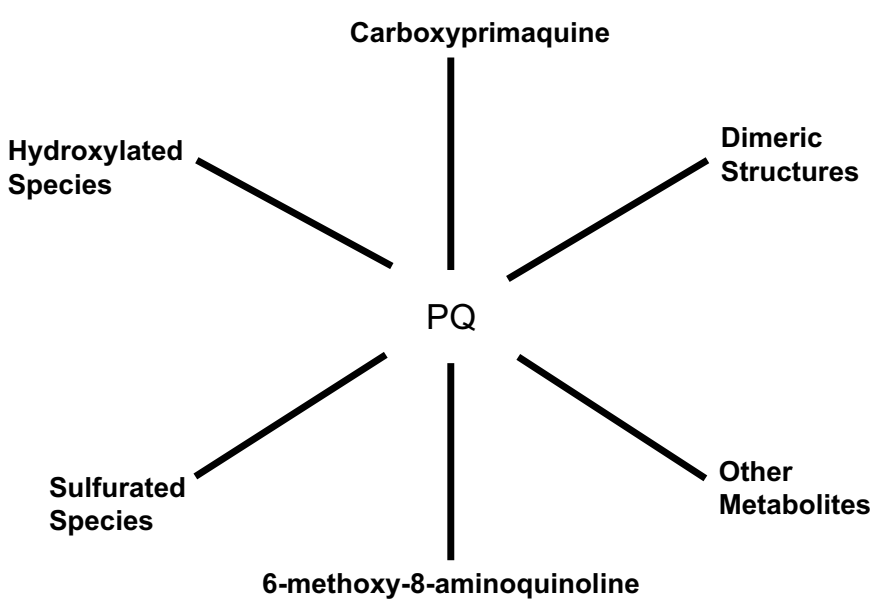

Scheme 1. Main PQ direct metabolites, according to in vitro and in vivo studies.

\subsection{Hemolysis}

As referred previously, $\mathrm{PQ}$ is not significantly active against blood stages of Plasmodium lifecycle [125]. However, it affects the host erythrocytes, especially in persons with deficiency of glucose6-phosphate dehydrogenase (G6PD), to whom PQ causes hemolytic anemia. In persons with normal levels of G6PD, hemolysis is not observed. The severity of hemolytic anemia seems to be related with PQ dosing and the degree of G6PD deficiency [14]. This serious side effect of $\mathrm{PQ}$ and other 8AQs has been reported over half a century ago [126-130] and has long been known to be due to intra-erythrocytic oxidative stress mediated by redox-active metabolites [131], as occurs in methemoglobinemia. Thus, the major side effects of PQ and other 8AQs are related to the toxicity of some of their metabolites. For example, 5-hydroxyprimaquine causes hemolytic anemia and generates reactive oxygen species (ROS), though it was not associated to lipid peroxidation or alteration of phosphatidylserine asymmetry. These observations are consistent with damage of cytoskeletal proteins, in the form of disulfide-linked hemoglobin adducts, leading to disruption and removal of affected erythrocytes [131].

\subsection{Gastrointestinal effects}

Abdominal pain and cramps are commonly reported when PQ is taken on an empty stomach [132]. About $10-12 \%$ of persons receiving $22.5-30 \mathrm{mg}$ of $\mathrm{PQ}$ per day presented mild to moderate abdominal cramps [133]. Administration of $240 \mathrm{mg} /$ day resulted in moderate to intolerably severe abdominal cramps and these higher doses also caused nausea and occasional vomiting. Mild diarrhoea has also been occasionally reported [14,132]. On the other hand, food intake was seen to increase the oral bioavailability of PQ, eventually leading to higher anti-malarial efficacy.

\subsection{Other adverse effects}

Other serious side effects associated with PQ are practically inexistent. Psychomotor alterations due to $\mathrm{PQ}$-based therapies were never registered, whereas neuropsychiatric side effects are very rare. To our best knowledge, only a single case of depression and psychosis after PQ administration was described so far [14]. Also, Schlossberg reported an isolated depression episode in a patient who after therapy with PQ presented mental confusion and hallucinations [134].

No other adverse effects of PQ have been noteworthy, even at overdosing. Only three reports of PQ overdose cases could be traced, and side effects observed were a consequence of methemoglobinemia [132].

Administration of lethal doses of PQ to experimental animals led to the appearance of cardiac lesions, but this effect has never been detected in humans [135]. In fact, though PQ blocks the inward sodium current $I_{\mathrm{Na}}$, slowing the upstroke of the action potential [108,136], the limited available evidence does not suggest significant cardiovascular toxicity [137].

\section{Relevant primaquine metabolites}

PQ is rapidly absorbed in the gastrointestinal tract and concentrated in the liver, brain, heart, lungs and skeletal muscle. The mean volume of distribution is $3 \mathrm{~L} / \mathrm{kg}$. It peaks in plasma within $1-3 \mathrm{~h}$, at $\sim 70 \mathrm{mg} / \mathrm{mL}$, and is rapidly excreted in urine, with a plasma half-life of 4-9 h [9]. PQ is primarily metabolised to

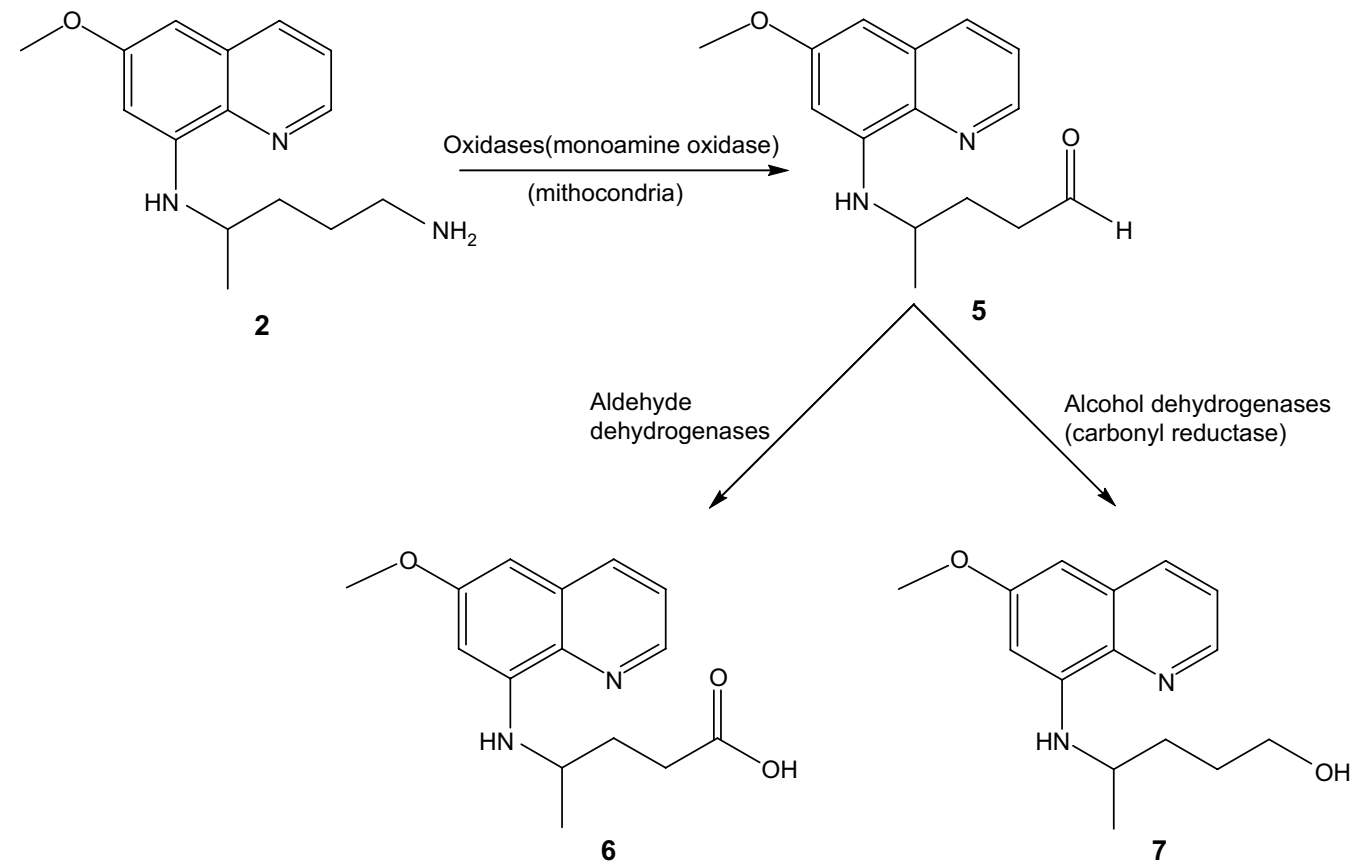

Scheme 2. Proposed pathways for side-chain metabolism of PQ. Adapted from Ref. [96]. 
carboxyprimaquine that is not accumulated in the body. PQ is also metabolised to a number of other identified and unidentified metabolites that are detectable in urine and plasma (Scheme 1). Only $\sim 1-4 \%$ of PQ is eliminated as the parent compound in urine [14].

\subsection{Carboxyprimaquine}

Metabolic transformations independent of cytochrome $\mathrm{P}_{450}$ apparently play a role in PQ clearance from the body. The side chain of PQ undergoes biotransformation to PQ-aldehyde (5, Scheme 2) in cell-free media containing an oxidase. PQ-aldehyde is then converted to carboxyprimaquine (6) by an aldehyde dehydrogenase. Alternatively, alcohol dehydrogenase may convert PQ to PQ alcohol (7) $[96,138]$. Carboxyprimaquine $(\mathbf{6})$ is the main metabolite of PQ and was identified in mice, monkeys and humans [139-145]. PQ is rapidly converted into 6 and the peak levels are reached within 3-12 h post-dose, attaining $1427 \pm 307 \mathrm{ng} / \mathrm{mL}$, carboxyprimaquine isomers have shown that the conversion is faster for (-)-PQ than for (+)-PQ which may explain the reason why (-)-PQ is less toxic than (+)-PQ [99].

\subsection{Hydroxylated species}

Metabolic hydroxylation of PQ represents an important role in the toxicity associated with its therapeutic use. The most representative hydroxylated metabolite is 5-hydroxyprimaquine (5-HPQ 8) [146-153]. According to Bowman et al. [146], this metabolite induced methemoglobin formation and depletion of glutathione $(\mathrm{GSH})$, when incubated with suspensions of rat erythrocytes. Data from this same work indicate that 5-HPQ has the requisite properties associated with the hematoxicity of PQ.

Other study demonstrated that spleen macrophages play a crucial role in the removal of 5-HPQ-treated rat erythrocytes from the circulation, reinforcing that 5-HPQ is an important contributor to the hemolytic response induced by PQ [147].<smiles>COc1cc(NC(C)CCCN)c2ncccc2c1O</smiles>

8<smiles>COc1cc(N)c2ncccc2c1O</smiles>

11<smiles>CC(CCCN)Nc1cc(O)cc2cccnc12</smiles>

9<smiles>Nc1cc(O)c(O)c2cccnc12</smiles>

12<smiles>CC(CCCN)Nc1cc(O)c(O)c2cccnc12</smiles>

10<smiles>Nc1cc(O)cc2cccnc12</smiles>

13<smiles>COc1cc(N(O)C(C)CCCN)c2ncccc2c1</smiles>

14<smiles>COc1cc(NC(C)CCCN)c2nccc(O)c2c1</smiles>

15 10-fold higher than those of the parent drug. Carboxyprimaquine has not been detected in urine, suggesting that it suffers additional metabolic transformations before excretion [141]. Carboxyprimaquine exhibits schizontocidal activity only at $50 \mathrm{mg} / \mathrm{L}$ (schizontocidal activity), being substantially less active than PQ which indicates that an ionisable amino group in the aliphatic moiety of the drug is an essential structural feature for activity [144]. On the other hand, the toxicity of carboxyprimaquine in terms of MetHb formation is lower than that of the parent drug [141]. Experiments to determine differences between PQ isomers in terms of their transformation into the corresponding
Hydrogen peroxide is the ultimate oxidant formed from 5-HPQ by redox-cycling of the corresponding quinone-imine derivative [148]. Another study evidenced that a double mechanism to oxyhemoglobin oxidation and the reduced glutathione (GSH) occurs by autoxidation of the 5-hydroxy-8-aminoquinolines and their coupled oxidation with oxyhemoglobin [149]. This phenomenon not only applies to 5-HPQ but also to other 5-hydroxylated metabolites such as 5,6-dihydroxyprimaquine (10), 6-methoxy-5-hydroxy-8aminoquinoline (11) and 5,6-dihydroxy-8-aminoquinoline (12). These oxidative processes yield free radicals, superoxide radical anions, hydrogen peroxide and, ultimately, methemoglobin [149]. 
The formation of hydrogen peroxide, quinone-imine metabolites, drug-derived free radicals and hydroxyl radicals were demonstrated in another study with 5-HPQ (8), 5,6-dihydroxy-8aminoquinoline (12) and 5,6-dihydroxyprimaquine (10) $[148,150]$. Metabolic incubation of this latter compound, under alkaline conditions and in the presence of organic solvents and light, has been reported to yield a three-ring quinine-imine blue product (16) that would exist in equilibrium with the orthoquinoid form (17, Scheme 3) [151].

Other hydroxylated metabolites of $\mathrm{PQ}$ potentially able to induce MetHb formation, are 6-desmethylprimaquine (9) and 4-hydroxyprimaquine (15), but these are formed in lower amounts than those of the aforementioned hydroxylated metabolites [152].

Finally, formation of $N^{8}$-hydroxyprimaquine (14) metabolite has also been proposed, but comparison of the metabolite alleged to be 14 with synthetic $N^{8}$-hydroxyprimaquine failed to confirm the hypothesis [153].

\subsection{6-Methoxy-8-aminoquinoline or MAQ}

6-Methoxy-8-aminoquinoline (MAQ 18) is thoroughly referenced in works devoted to PQ metabolism [148,151-155]. MAQ is not very active in inducing MetHb formation, thus shows lower toxicity indices as compared to other PQ metabolites [148,152,153]. However, an early report of Bolchoz et al. described that, when MAQ was incubated with rat and human liver microsomes, a single metabolite of MAQ was detected and identified as 6-methoxy-8- $(\mathrm{N}-$ hydroxy)aminoquinoline (MAQ-NOH, 19). This compound was responsible for causing hemolysis in vivo as well as for inducing the formation of MetHb when incubated with suspensions of rat erythrocytes [154]. One year later, the same authors demonstrated that, under hemolytic conditions, MAQ-NOH generates three oxygen-active species in rat erythrocytes: hydroxyl radical, hydrogen peroxide and ferryl heme, responsible for hemolytic anemia [155].<smiles>COc1cc(N)c2ncccc2c1</smiles><smiles>COc1cc(NO)c2ncccc2c1</smiles>

\subsection{Dimeric compounds}

To better understand PQ metabolism, PQ degradation by microbial enzymes was studied and two new dimeric metabolites of PQ $(\mathbf{2 0}, \mathbf{2 1})$ were identified [156,157]. These dimers of $\mathrm{N}$-acetylprimaquine were inactive in vitro as anti-malarials, thus reinforcing the idea that the free primary amino group on the aliphatic chain of PQ is essential for anti-malarial activity [156,157]. Peroxodisulfate oxidation of $P Q$ has also been shown to produce dimeric derivatives of the unacetylated drug $(\mathbf{2 2}, \mathbf{2 3})$, both of which were active as schizontocides [158]. Moreover, compound 22 was found to have a gametocytocidal activity superior to that of $\mathrm{PQ}$ whereas compound 23 was significantly less active [158].

\subsection{Sulfur compounds}

In addition to $N$-acetyl PQ dimers $\mathbf{2 0}$ and $\mathbf{2 1}$ isolated in microbial metabolism studies, a sulfur-bridged dimer (24) and a thio-quinone-imine metabolite (25) were also proposed on the basis of spectral and chemical data [159]. The relevance of this discovery relies on what can be the sulfur source for in vivo formation of these metabolites, with glutathione being one of the hypothesized sources [159].<smiles>COc1cc(NC(C)CCCNC(C)=O)c2ncccc2c1-c1c(OC)cc(NC(C)CCCNC(C)=O)c2ncccc12</smiles>

20<smiles>COc1cc(NC(C)CCCN)c2ncccc2c1-c1c(OC)cc(NC(C)CCCN)c2ncccc12</smiles>
22<smiles>[Z17]C(C)Nc1cc(OC)c(Cc2c(OC)cc(NC(C)CCCNC(C)=O)c3ncccc23)c2cccnc12</smiles><smiles>COc1c(O)c(NC(C)CCCN)c2ncccc2c1-c1c(OC)c(O)c(NC(C)CCCN)c2ncccc12</smiles>

23<smiles>[Z4]CCCNC(C)=O</smiles><smiles>COC1=C/C(=N/C(C)CCCNC(C)=O)c2ncccc2C1=S</smiles>

25

\subsection{Other compounds}

Some microbial metabolism studies confirmed the formation of $\mathrm{N}$-acetylprimaquine (26) metabolite [139,140,156], but this has not been detected in human plasma or urine [141]. Metabolic 


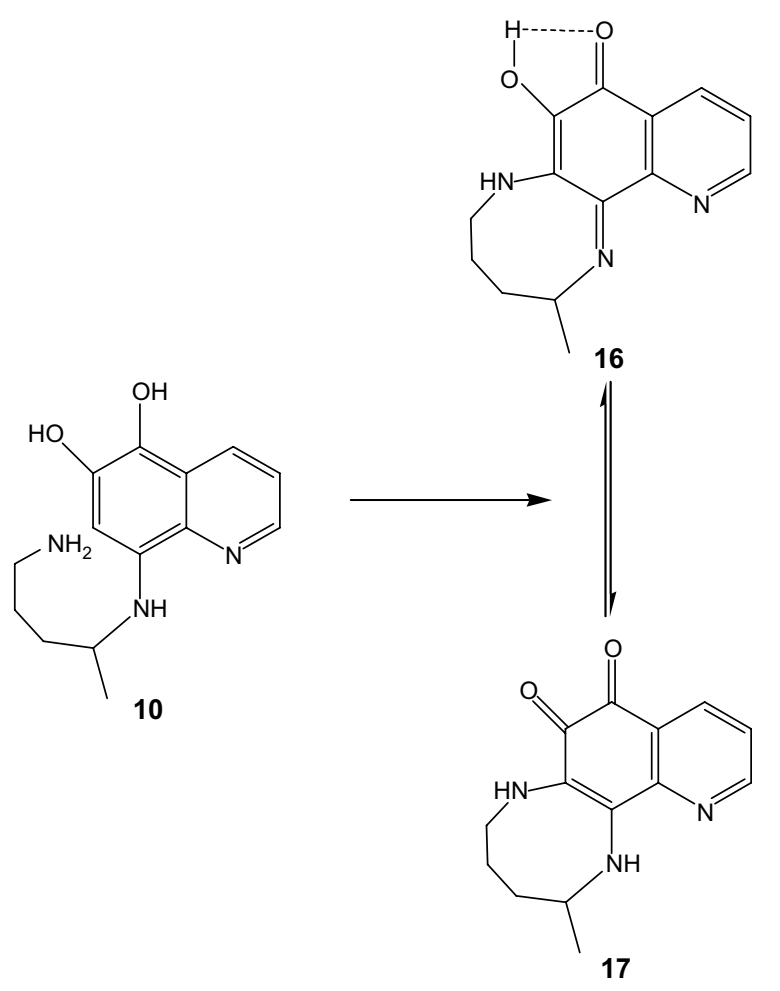

Scheme 3. Conversion of the hydroxylated metabolite $\mathbf{1 0}$ into a three-ring quinineimine blue product (16) in equilibrium with its orthoquinoid form (17) [151].

production of both the PQ methyl ester (27), i.e., with a terminal urethane $[139,140]$ and amide $(\mathbf{2 8})$, with a terminal urea, [140,156] has also been detected.

Other PQ metabolites have been described, such as compound 29 that is formed by peroxodisulfate oxidation of $\mathrm{PQ}$. Biologic studies have revealed that this PQ derivative can be a novel antimalarial with good gametocytocidal activity [158]. transformations. Therefore, introduction of substituents on the quinoline ring and modification of the terminal primary amino group have been the main targets for PQ modification and only these will be referred to in some detail.

\subsection{Modifications at the quinoline ring}

Over the last six decades, one of the strategies aimed at improving the therapeutic efficacy of PQ while reducing its toxicity has been the introduction of substituent groups at positions $2,3,4$, 5 and 7 of the quinolinic ring [160]. This produced almost $200 \mathrm{PQ}$ derivatives (Tables 2-4) bearing diverse groups in one or more given positions of the ring [6,46,161-179]. Globally, the most favourable substituent insertions towards anti-malarial activity where those of methyl groups at positions 4 and 2, tert-butyl at position 2, simultaneous insertion of ethyl substituents at positions 2 and 4 and pentyloxy at position 5 , as well as insertion at position 5 of alkoxy, fluoro, and 3- or 4-substituted phenoxy groups [51,163]. Many of these compounds present activity comparable or superior to that of PQ both as gametocytocide and schizontocide, as further described below.

2-Ethyl- and 4-methylprimaquines were evaluated against $P$. cynomolgi in rhesus monkeys, where they were as active as the parent drug [162]. 4-Methylprimaquine was approximately twice as active as PQ in test animals, with $8 / 12$ cures at a dose of $0.25 \mathrm{mg} / \mathrm{kg}$ against $P$. cynomolgi in infected rhesus monkeys, being apparently less toxic. However, other alkyl groups inserted at the quinoline's C-4 led to the loss of radical curative anti-malarial activity, even though they were also somewhat less toxic than PQ $[169,171]$. These findings led to the synthesis of several derivatives from 4-methylprimaquine, for instance, by introduction of aryloxy groups at position 5 . The compounds were not only significantly superior to PQ as radical curative agents, but were also highly effective as suppressive agents [172]. Compounds 128a and 129a (Table 3) were significantly effective against established Pneumocystis carinii infections in the rat model when administered intraperitoneally or orally [46]. Insertion of alkoxy instead of<smiles>COc1cc(NC(C)CCCNC(C)=O)c2ncccc2c1</smiles>

26<smiles>COc1cc(NC(C)CCCNC(N)=O)c2ncccc2c1</smiles>

28<smiles>COC(=O)NCCCC(C)Nc1cc(OC)cc2cccnc12</smiles>

27<smiles>COc1cc(NC(C)CCCN)c2ncccc2c1NC(C)CCCN</smiles>

\section{4. $P Q$ as scaffold for novel drugs}

There have been two main routes for the direct modification of $\mathrm{PQ}$ on the basis of its most representative metabolic aryloxy substituents in position 5 of 4-methylprimaquine generally produced a very pronounced increase in activity at the lower half of the dosage range, without diminishing toxicity at higher doses [174]. 
Table 2

PQ derivatives obtained by substitution at positions 2 and 3 of the quinoline ring

\begin{tabular}{|c|c|c|c|}
\hline $\begin{array}{l}\text { Ring } \\
\text { position }\end{array}$ & No. & Substituent group(s) & References \\
\hline \multirow[t]{54}{*}{2} & $1 \mathbf{a}$ & $-\mathrm{OCH}_{3}$ & {$[161,163]$} \\
\hline & $\mathbf{2 a}$ & $-\mathrm{NH}_{2}$ & {$[161,163]$} \\
\hline & 3a & $-\mathrm{N}\left(\mathrm{CH}_{3}\right)_{2}$ & [161] \\
\hline & $4 a$ & $-\mathrm{Cl}$ & {$[161,163]$} \\
\hline & $5 \mathbf{a}$ & $-\mathrm{C}_{2} \mathrm{H}_{5}$ & {$[161,163]$} \\
\hline & $\mathbf{6 a}$ & $-\mathrm{CH}=\mathrm{CH}_{2}$ & {$[161]$} \\
\hline & $7 a$ & $-\mathrm{CH}_{2} \mathrm{H}_{5},-\mathrm{CH}_{3}$ (pos. 4) & [162] \\
\hline & $\mathbf{8 a}$ & $-\mathrm{CH}=\mathrm{CH}_{2},-\mathrm{CH}_{3}($ pos. 4) & [162] \\
\hline & 9a & $-\mathrm{CH}_{3},-\mathrm{C}_{2} \mathrm{H}_{5}($ pos. 4$)$ & [162] \\
\hline & $10 \mathbf{a}$ & $-\mathrm{CH}_{3}$ & [163] \\
\hline & $11 a$ & $-\mathrm{CF}_{3}$ & [163] \\
\hline & $12 a$ & $-\mathrm{CH}_{2} \mathrm{OH}$ & [163] \\
\hline & 13a & $-\mathrm{C}_{6} \mathrm{H}_{4}(4-\mathrm{Cl})$ & [163] \\
\hline & $14 a$ & $-\mathrm{OCH}_{2}-\mathrm{Ph}$ & [163] \\
\hline & $15 a$ & $-\mathrm{OCH}_{2}-\mathrm{C}_{6} \mathrm{H}_{4}\left(4-\mathrm{OCH}_{3}\right)$ & [163] \\
\hline & $16 \mathbf{a}$ & $-\mathrm{OCH}_{2}-\mathrm{C}_{6} \mathrm{H}_{4}(4-\mathrm{F})$ & [163] \\
\hline & $17 \mathbf{a}$ & $-\mathrm{OCH}_{2}-\mathrm{C}_{6} \mathrm{H}_{4}\left(4-\mathrm{CF}_{3}\right)$ & [163] \\
\hline & $18 \mathbf{a}$ & $-\mathrm{OCH}_{2}-\mathrm{C}_{6} \mathrm{H}_{4}\left(3-\mathrm{CF}_{3}\right)$ & [163] \\
\hline & $19 a$ & $-\mathrm{OCH}_{2}-\mathrm{C}_{6} \mathrm{H}_{4}(4-\mathrm{Cl})$ & [163] \\
\hline & $20 a$ & $-\mathrm{OCH}_{2}-\mathrm{C}_{6} \mathrm{H}_{3}\left(2,4-\mathrm{Cl}_{2}\right)$ & [163] \\
\hline & 21a & $-\mathrm{CH}=\mathrm{CH}-\mathrm{C}_{6} \mathrm{H}_{4}(4-\mathrm{Cl})$ & [163] \\
\hline & 22a & $-\mathrm{SCH}_{2}-\mathrm{Ph}$ & [163] \\
\hline & 23a & $-\mathrm{SCH}_{2}-\mathrm{C}_{6} \mathrm{H}_{4}(4-\mathrm{Cl})$ & [163] \\
\hline & $24 a$ & $-\mathrm{CH}_{3},-\mathrm{CH}_{3}$ (pos. 4) & [163] \\
\hline & 25a & $-\mathrm{CH}_{3},-\mathrm{O}-\mathrm{C}_{6} \mathrm{H}_{4}(4-\mathrm{Cl})($ pos. 4$)$ & [163] \\
\hline & 26a & $-\mathrm{CH}_{3},-\mathrm{CH}_{3}($ pos. 5$)$ & [163] \\
\hline & $27 a$ & $-\mathrm{CH}_{3},-\mathrm{F}($ pos. 5$)$ & [163] \\
\hline & 28a & $-\mathrm{CH}_{3},-\mathrm{O}-\mathrm{C}_{6} \mathrm{H}_{4}(4-\mathrm{Cl})($ pos. 5) & [163] \\
\hline & 29a & $-\mathrm{CH}_{3},-\mathrm{O}-\mathrm{C}_{6} \mathrm{H}_{4}(4-\mathrm{F})($ pos. 5) & [163] \\
\hline & 30a & $-\mathrm{CH}_{3},-\mathrm{O}-\mathrm{C}_{6} \mathrm{H}_{4}\left(3-\mathrm{CF}_{3}\right)($ pos. 5) & [163] \\
\hline & $31 a$ & $-\mathrm{CH}_{3},-\mathrm{S}-\mathrm{C}_{6} \mathrm{H}_{4}(4-\mathrm{Cl})($ pos. 5) & [163] \\
\hline & $32 a$ & $-\mathrm{CH}\left(\mathrm{CH}_{3}\right)_{2}$ & [164] \\
\hline & 33a & $-\mathrm{CH}\left(\mathrm{CH}_{3}\right)_{2},-\mathrm{CH}\left(\mathrm{CH}_{3}\right)_{2}$ (pos. 5) & [164] \\
\hline & $34 a$ & $-c-\mathrm{C}_{5} \mathrm{H}_{9}$ & [164] \\
\hline & 35a & $-c-\mathrm{C}_{5} \mathrm{H}_{9},-c-\mathrm{C}_{5} \mathrm{H}_{9}$ (pos. 5) & [164] \\
\hline & $36 \mathbf{a}$ & $-c-\mathrm{C}_{6} \mathrm{H}_{11}$ & [164] \\
\hline & $37 \mathbf{a}$ & $-c-\mathrm{C}_{6} \mathrm{H}_{11},-c-\mathrm{C}_{6} \mathrm{H}_{11}$ (pos. 5) & [164] \\
\hline & $38 \mathbf{a}$ & $-\mathrm{CH}\left(\mathrm{CH}_{3}\right)_{2},-\mathrm{OCH}_{3}($ pos. 5$)$ & [164] \\
\hline & $39 a$ & $-\mathrm{C}\left(\mathrm{CH}_{3}\right)_{3},-\mathrm{OCH}_{3}$ (Pos. 5) & {$[164]$} \\
\hline & $40 a$ & $-c-\mathrm{C}_{6} \mathrm{H}_{11},-\mathrm{OCH}_{3}($ pos. 5) & {$[164]$} \\
\hline & 41a & $-\mathrm{C}\left(\mathrm{CH}_{3}\right)_{3}$ & {$[164,165,167]$} \\
\hline & $42 a$ & -1-adamantyl & {$[165]$} \\
\hline & $43 a$ & $-\mathrm{C}\left(\mathrm{CH}_{3}\right)_{3},-\mathrm{O}-\mathrm{C}_{6} \mathrm{H}_{4}\left(3-\mathrm{CF}_{3}\right)($ pos. 5) & [167] \\
\hline & $44 a$ & $-\mathrm{C}\left(\mathrm{CH}_{3}\right)_{3},-\mathrm{CH}_{3}\left(\right.$ pos.4), $-\mathrm{O}-\mathrm{C}_{6} \mathrm{H}_{4}\left(3-\mathrm{CF}_{3}\right)($ pos. 5) & [167] \\
\hline & 45a & $-\mathrm{C}\left(\mathrm{CH}_{3}\right)_{3},-\mathrm{C}_{2} \mathrm{H}_{5}\left(\right.$ pos.4), $-\mathrm{O}-\mathrm{C}_{6} \mathrm{H}_{4}\left(3-\mathrm{CF}_{3}\right)($ pos. 5$)$ & [167] \\
\hline & 46a & $-\mathrm{CH}_{3},-\mathrm{O}-\left(n-\mathrm{C}_{6} \mathrm{H}_{13}\right)($ pos. 5) & {$[165]$} \\
\hline & $47 a$ & $-\mathrm{CH}_{3},-\mathrm{CH}_{3}$ (pos. 4), -O- $\left(n-\mathrm{C}_{6} \mathrm{H}_{13}\right)($ pos. 5) & {$[165]$} \\
\hline & $48 a$ & $-\mathrm{OCH}_{3},-\mathrm{CH}_{3}($ pos. 4$),-\mathrm{O}-\mathrm{C}_{6} \mathrm{H}_{4}\left(3-\mathrm{CF}_{3}\right)($ pos. 5$)$ & [167] \\
\hline & $49 a$ & $\begin{array}{l}-\mathrm{O}-\mathrm{C}_{6} \mathrm{H}_{4}(4-\mathrm{Cl}),-\mathrm{CH}_{3} \text { (pos. 4), }-\mathrm{O}-\mathrm{C}_{6} \mathrm{H}_{4}\left(3-\mathrm{CF}_{3}\right) \\
(\text { pos. } 5)\end{array}$ & [167] \\
\hline & $50 a$ & $\begin{array}{l}\left.-\mathrm{OCH}_{2}-\mathrm{C}_{6} \mathrm{H}_{4}(4-\mathrm{Cl}),-\mathrm{CH}_{3} \text { (pos. } 4\right),-\mathrm{O}-\mathrm{C}_{6} \mathrm{H}_{4}\left(3-\mathrm{CF}_{3}\right) \\
\text { (Pos. 5) }\end{array}$ & [167] \\
\hline & 51a & $-\mathrm{OH},-\mathrm{CH}_{3}($ pos. 4$),-\mathrm{O}-\mathrm{C}_{6} \mathrm{H}_{4}\left(3-\mathrm{CF}_{3}\right)($ pos. 5$)$ & {$[167,175]$} \\
\hline & $52 a$ & $-\mathrm{OCH}_{3},-\mathrm{CH}_{3}$ (pos. 4) & [167] \\
\hline & 53a & $-\mathrm{OCH}_{3},-\mathrm{CH}_{3}\left(\right.$ pos. 4), $-\mathrm{O}-\left(\mathrm{CH}_{2}\right)_{5} \mathrm{CH}_{3}$ (pos. 5) & [167] \\
\hline & $54 a$ & $-\mathrm{OCH}_{3},-\mathrm{CH}_{3}$ (pos. 4), $-\mathrm{OCH}_{2}-\mathrm{C}_{6} \mathrm{H}_{4}\left(3-\mathrm{CF}_{3}\right)($ pos. 5) & [167] \\
\hline \multirow[t]{6}{*}{3} & $55 a$ & $-\mathrm{CH}_{3}$ & {$[163,174]$} \\
\hline & $56 a$ & $-\mathrm{CH}_{3},-\mathrm{CH}_{3}$ (pos. 4) & [163] \\
\hline & $57 a$ & $-\mathrm{CH}_{3},-\mathrm{O}-\mathrm{C}_{6} \mathrm{H}_{3}\left(3-\mathrm{CF}_{3}, 4-\mathrm{F}\right)($ pos. 5) & [168] \\
\hline & $58 \mathbf{a}$ & $-\mathrm{CH}_{3},-\mathrm{O}-\left(n-\mathrm{C}_{6} \mathrm{H}_{13}\right)($ pos. 5) & [174] \\
\hline & $59 a$ & $-\mathrm{CH}_{3},-\mathrm{O}-\left(2-\mathrm{C}_{6} \mathrm{H}_{12}\right)($ pos. 5) & {$[174]$} \\
\hline & $60 a$ & $-\mathrm{CH}_{3},-\mathrm{O}-\left(3-\mathrm{C}_{6} \mathrm{H}_{12}\right)($ pos. 5) & [174] \\
\hline
\end{tabular}

Monosubstituted derivatives with phenoxy groups on C-5 were reasonably active, some of them having lower toxicity than PQ. Also in this case, introduction of a methyl group on C-3 or C-4 of several 5-phenoxyprimaquines drastically increased the blood-schizontocidal activity [168].

Recently, 2-tert-butylprimaquine was presented to the scientific community as being the first $8 \mathrm{AQ}$ completely devoid of MetHb toxicity, possibly through blockade of a relevant degradation
Table 3

PQ derivatives obtained by substitution at position 4 of the quinoline ring

\begin{tabular}{|c|c|c|c|}
\hline Ring position & No. & Substituent group(s) & References \\
\hline \multirow[t]{76}{*}{$\overline{4}$} & 61a & $-\mathrm{CH}_{3}$ & $\overline{[169,170,174]}$ \\
\hline & $62 a$ & $-\mathrm{CH}_{2} \mathrm{OH}$ & [163] \\
\hline & $63 a$ & $-\mathrm{CH}=\mathrm{CH}_{2}$ & {$[163,171,173]$} \\
\hline & $64 a$ & $-\left(\mathrm{CH}_{2}\right)_{2} \mathrm{CH}_{3}$ & [163] \\
\hline & $65 a$ & $-\mathrm{CH}=\mathrm{CHCH}_{3}$ & [163] \\
\hline & $66 a$ & $-\left(\mathrm{CH}_{2}\right)_{3} \mathrm{CH}_{3}$ & [163] \\
\hline & $67 a$ & $-\mathrm{CH}=\mathrm{CHC}_{2} \mathrm{H}_{5}$ & [163] \\
\hline & $68 a$ & $-\mathrm{CH}_{2} \mathrm{CH}\left(\mathrm{CH}_{3}\right) \mathrm{C}_{2} \mathrm{H}_{5}$ & [163] \\
\hline & $69 a$ & $-\mathrm{CH}_{2}-\mathrm{C}_{6} \mathrm{H}_{11}$ & [163] \\
\hline & $70 a$ & $-\left(\mathrm{CH}_{2}\right)_{3}-\mathrm{C}_{6} \mathrm{H}_{11}$ & [163] \\
\hline & 71a & $-\left(\mathrm{CH}_{2}\right)_{2}-\mathrm{C}_{6} \mathrm{H}_{4}(4-\mathrm{Cl})$ & [163] \\
\hline & $72 a$ & $-\mathrm{CH}=\mathrm{CH}-\mathrm{C}_{6} \mathrm{H}_{4}(4-\mathrm{Cl})$ & [163] \\
\hline & $73 a$ & $-\mathrm{CH}=\mathrm{CH}-\mathrm{C}_{6} \mathrm{H}_{4}(3-\mathrm{Cl})$ & [163] \\
\hline & $74 a$ & $-\left(\mathrm{CH}_{2}\right)_{2} \mathrm{~S}-\mathrm{C}_{6} \mathrm{H}_{4}(4-\mathrm{F})$ & {$[163,171]$} \\
\hline & $75 a$ & $-\mathrm{CF}_{3}$ & [163] \\
\hline & $76 a$ & $-\mathrm{OH}$ & [163] \\
\hline & $77 a$ & $-\mathrm{OCH}_{3}$ & {$[163,169]$} \\
\hline & $78 a$ & $-\mathrm{O}-\mathrm{C}_{6} \mathrm{H}_{4}(4-\mathrm{Cl})$ & {$[163,169]$} \\
\hline & $79 a$ & $-\mathrm{O}-\mathrm{C}_{6} \mathrm{H}_{4}\left(4-\mathrm{OCH}_{3}\right)$ & {$[163,169]$} \\
\hline & $80 a$ & $-\mathrm{O}-\mathrm{CH}_{2}-\mathrm{C}_{6} \mathrm{H}_{4}(4-\mathrm{Cl})$ & {$[163,169]$} \\
\hline & $81 a$ & $-\mathrm{SCH}_{3}$ & {$[163,169]$} \\
\hline & $82 a$ & $-\mathrm{S}-\mathrm{C}_{6} \mathrm{H}_{4}(4-\mathrm{Cl})$ & {$[163,169]$} \\
\hline & $83 a$ & $-\mathrm{S}-\mathrm{C}_{6} \mathrm{H}_{4}\left(4-\mathrm{OCH}_{3}\right)$ & {$[163,169]$} \\
\hline & $84 a$ & $-\mathrm{NH}_{2}$ & {$[163,169]$} \\
\hline & $85 a$ & $-\mathrm{NHCH}_{3}$ & {$[163,169]$} \\
\hline & $86 a$ & $-\mathrm{NH}-\mathrm{C}_{6} \mathrm{H}_{4}(4-\mathrm{Cl})$ & {$[163,169]$} \\
\hline & $87 a$ & $-\mathrm{CH}_{3},-\mathrm{OCH}_{3}($ pos. 5$)$ & {$[163,173]$} \\
\hline & $88 a$ & $-\mathrm{CH}_{3},-\mathrm{O}-\mathrm{C}_{6} \mathrm{H}_{4}\left(3-\mathrm{CF}_{3}\right)($ pos. 5$)$ & {$[163,172]$} \\
\hline & $89 a$ & $-\mathrm{CH}_{3},-\mathrm{F}($ pos. 5$)$ & [163] \\
\hline & $90 a$ & $-\mathrm{CH}_{3},-\mathrm{Cl}($ pos. 5$)$ & [163] \\
\hline & 91a & $-\mathrm{CH}_{3},-\mathrm{O}-\mathrm{C}_{6} \mathrm{H}_{5}$ (pos. 5) & [168] \\
\hline & $92 a$ & $-\mathrm{CH}_{3},-\mathrm{O}-\mathrm{C}_{6} \mathrm{H}_{3}\left(3,5-\left(\mathrm{CF}_{3}\right)_{2}\right)($ pos. 5) & {$[168]$} \\
\hline & 93a & $-\mathrm{CH}_{3},-\mathrm{O}-\mathrm{C}_{6} \mathrm{H}_{3}\left(3-\mathrm{CF}_{3}, 4-\mathrm{F}\right)($ pos. 5) & [168] \\
\hline & $94 a$ & $-\mathrm{O}-\mathrm{C}_{6} \mathrm{H}_{3}\left(3,4-\mathrm{Cl}_{2}\right)$ & [169] \\
\hline & 95a & $-\mathrm{O}-\mathrm{C}_{6} \mathrm{H}_{4}\left(3-\mathrm{CF}_{3}\right)$ & [169] \\
\hline & $96 a$ & $-\mathrm{NHC}(\mathrm{O}) \mathrm{CH}_{3}$ & [169] \\
\hline & 97a & $-\left(\mathrm{CH}_{2}\right)_{2} \mathrm{~S}-\mathrm{C}_{6} \mathrm{H}_{4}\left(4-\mathrm{OCH}_{3}\right)$ & [171] \\
\hline & 98a & $-\left(\mathrm{CH}_{2}\right)_{2} \mathrm{~S}-\mathrm{C}_{6} \mathrm{H}_{4}(4-\mathrm{Cl})$ & [171] \\
\hline & 99a & $-\mathrm{CH}_{2} \mathrm{CH}_{3}$ & [171] \\
\hline & $100 a$ & $-\mathrm{CH}_{3},-\mathrm{O}-\mathrm{C}_{6} \mathrm{H}_{3}\left(2,4-\mathrm{Cl}_{2}\right)($ pos. 5) & [172] \\
\hline & $101 a$ & $-\mathrm{CH}_{3},-\mathrm{O}-\mathrm{C}_{6} \mathrm{H}_{3}\left(3,4-\mathrm{Cl}_{2}\right)$ (pos. 5) & [172] \\
\hline & $102 a$ & $-\mathrm{CH}_{3},-\mathrm{O}-\mathrm{C}_{6} \mathrm{H}_{4}\left(4-\mathrm{OCH}_{3}\right)($ pos. 5) & {$[172]$} \\
\hline & $103 a$ & $-\mathrm{CH}_{3},-\mathrm{O}-\mathrm{C}_{6} \mathrm{H}_{4}(4-\mathrm{F})($ pos. 5) & [172] \\
\hline & $104 a$ & $-\mathrm{CH}_{2} \mathrm{OCH}_{3},-\mathrm{O}-\mathrm{C}_{6} \mathrm{H}_{4}\left(3-\mathrm{CF}_{3}\right)($ pos. 5) & [173] \\
\hline & $105 a$ & $-\mathrm{CH}=\mathrm{CH}_{2},-\mathrm{O}-\mathrm{CH}_{3}$ (pos. 5) & [173] \\
\hline & $106 a$ & $-\mathrm{CH}_{2} \mathrm{O}-\mathrm{C}_{6} \mathrm{H}_{4}\left(3-\mathrm{CF}_{3}\right),-\mathrm{OCH}_{3}$ (pos. 5) & [173] \\
\hline & $107 a$ & $-\mathrm{CH}_{2} \mathrm{O}-\mathrm{C}_{6} \mathrm{H}_{4}\left(3-\mathrm{CF}_{3}\right),-\mathrm{O}-\mathrm{C}_{6} \mathrm{H}_{4}\left(3-\mathrm{CF}_{3}\right)$ & [173] \\
\hline & $108 \mathbf{a}$ & $-\mathrm{CH}_{3},-\mathrm{O}-\left(n-\mathrm{C}_{3} \mathrm{H}_{7}\right)($ pos. 5$)$ & [174] \\
\hline & $109 a$ & $-\mathrm{CH}_{3},-\mathrm{O}-\left(n-\mathrm{C}_{4} \mathrm{H}_{9}\right)($ pos. 5$)$ & {$[174]$} \\
\hline & $110 a$ & $-\mathrm{CH}_{3},-\mathrm{O}-\left(n-\mathrm{C}_{5} \mathrm{H}_{11}\right)($ pos. 5$)$ & [174] \\
\hline & $111 a$ & $-\mathrm{CH}_{3},-\mathrm{O}-\left(n-\mathrm{C}_{6} \mathrm{H}_{12}\right)($ pos. 5) & {$[174]$} \\
\hline & $112 a$ & $-\mathrm{CH}_{3},-\mathrm{O}-\left(n-\mathrm{C}_{7} \mathrm{H}_{15}\right)($ pos. 5$)$ & {$[174]$} \\
\hline & 113a & $-\mathrm{CH}_{3},-\mathrm{O}-\left(n-\mathrm{C}_{8} \mathrm{H}_{17}\right)($ pos. 5) & [174] \\
\hline & $114 a$ & $-\mathrm{CH}_{3},-\mathrm{O}-\left(n-\mathrm{C}_{9} \mathrm{H}_{19}\right)($ pos. 5$)$ & [174] \\
\hline & 115a & $-\mathrm{CH}_{3},-\mathrm{O}-\left(n-\mathrm{C}_{10} \mathrm{H}_{21}\right)($ pos. 5$)$ & [174] \\
\hline & 116a & $-\mathrm{CH}_{3},-\mathrm{O}-\left(n-\mathrm{C}_{11} \mathrm{H}_{23}\right)($ pos. 5$)$ & {$[174]$} \\
\hline & $117 a$ & $-\mathrm{CH}_{3},-\mathrm{O}-\left(n-\mathrm{C}_{12} \mathrm{H}_{25}\right)($ pos. 5) & [174] \\
\hline & $118 \mathbf{a}$ & $-\mathrm{CH}_{3},-\mathrm{O}-\left(\mathrm{CH}_{2}\right)_{4}-\mathrm{OPh}$ (pos. 5) & [174] \\
\hline & 119a & $-\mathrm{CH}_{3},-\mathrm{O}-\left(\mathrm{CH}_{2}\right)_{6}-\mathrm{OPh}$ (pos. 5) & {$[174]$} \\
\hline & $120 a$ & $-\mathrm{CH}_{3},-\mathrm{O}-\left(\mathrm{CH}_{2}\right)_{8}-\mathrm{OPh}$ (pos. 5) & {$[174]$} \\
\hline & $121 a$ & $-\mathrm{CH}_{3},-\mathrm{O}-\mathrm{CH}_{2} \mathrm{C}_{6} \mathrm{H}_{11}$ (pos. 5) & {$[174]$} \\
\hline & $122 a$ & $-\mathrm{CH}_{3},-\mathrm{O}-\mathrm{C}_{5} \mathrm{H}_{9}$ (pos. 5) & {$[174]$} \\
\hline & $123 a$ & $-\mathrm{CH}_{3},-\mathrm{O}-\left(\mathrm{CH}_{2}\right)_{2} \mathrm{CH}_{3}$ (pos. 5) & [174] \\
\hline & $124 a$ & $-\mathrm{CH}_{3},-\mathrm{O}-\left(\mathrm{CH}_{2}\right)_{2}-\mathrm{O}-\left(\mathrm{CH}_{2}\right)_{8} \mathrm{CH}_{3}$ (pos. 5) & {$[174]$} \\
\hline & $125 a$ & $-\mathrm{CH}_{3},-\mathrm{O}-\left(\mathrm{CH}_{2}\right)_{6}-\mathrm{O}-\mathrm{CH}_{3}$ (pos. 5) & [174] \\
\hline & $126 a$ & $-\mathrm{CH}_{3},-\mathrm{O}-\left(\mathrm{CH}_{2}\right)_{6}-\mathrm{O}-\mathrm{CH}_{2} \mathrm{Ph}$ (pos. 5) & {$[174]$} \\
\hline & $127 a$ & $-\mathrm{CH}_{3},-\mathrm{O}-\mathrm{CH}_{3}($ pos. 5$)$ & {$[174]$} \\
\hline & $128 a$ & $-\mathrm{CH}_{3},-\mathrm{O}-\mathrm{C}_{6} \mathrm{H}_{4}\left(4-\mathrm{O}-\mathrm{C}_{2} \mathrm{H}_{5}\right)($ pos. 5) & [46] \\
\hline & $129 a$ & $-\mathrm{CH}_{3},-\mathrm{O}-\mathrm{C}_{6} \mathrm{H}_{4}-\mathrm{O}-\left(n-\mathrm{C}_{7} \mathrm{H}_{15}\right)($ pos. 5) & [46] \\
\hline & $130 a$ & $-\mathrm{CH}_{3},-\mathrm{O}-\mathrm{C}_{6} \mathrm{H}_{4}-\mathrm{O}-\left(n-\mathrm{C}_{16} \mathrm{H}_{33}\right)($ pos. 5) & [46] \\
\hline & $131 a$ & $-\mathrm{C}_{2} \mathrm{H}_{5},-\mathrm{O}-\mathrm{C}_{3} \mathrm{H}_{7}$ (pos. 5) & {$[176,177]$} \\
\hline & $132 a$ & $-\mathrm{C}_{2} \mathrm{H}_{5},-\mathrm{O}-\mathrm{C}_{4} \mathrm{H}_{9}$ (pos. 5) & {$[176,177]$} \\
\hline & $133 a$ & $-\mathrm{C}_{2} \mathrm{H}_{5},-\mathrm{O}-\mathrm{C}_{5} \mathrm{H}_{11}$ (pos. 5 ) & {$[176,177]$} \\
\hline & $134 a$ & $-\mathrm{C}_{2} \mathrm{H}_{5},-\mathrm{O}-\mathrm{C}_{6} \mathrm{H}_{13}$ (pos. 5) & {$[176,177]$} \\
\hline & 135a & $-\mathrm{C}_{2} \mathrm{H}_{5},-\mathrm{O}-\mathrm{C}_{7} \mathrm{H}_{15}$ (pos. 5) & {$[176,177]$} \\
\hline & $136 a$ & $-\mathrm{C}_{2} \mathrm{H}_{5},-\mathrm{O}-\mathrm{C}_{8} \mathrm{H}_{17}$ (pos. 5) & {$[176,177]$} \\
\hline
\end{tabular}


Table 4

PQ derivatives obtained by substituent insertion at positions 5 and 7 of the quinoline ring

\begin{tabular}{|c|c|c|c|}
\hline Ring position & No. & Substituent group(s) & References \\
\hline \multirow[t]{34}{*}{5} & $137 a$ & $-\mathrm{O}-\mathrm{CH}_{3}$ & {$[6,163,179]$} \\
\hline & 138a & $-\mathrm{O}-\mathrm{C}_{2} \mathrm{H}_{5}$ & [163] \\
\hline & 139a & $-\mathrm{O}-\mathrm{C}_{6} \mathrm{H}_{4}(4-\mathrm{Cl})$ & {$[163,168,178]$} \\
\hline & $140 a$ & $-\mathrm{O}-\mathrm{C}_{6} \mathrm{H}_{4}(4-\mathrm{F})$ & {$[163,168,178]$} \\
\hline & 141a & $-\mathrm{O}-\mathrm{C}_{6} \mathrm{H}_{4}\left(3-\mathrm{CF}_{3}\right)$ & {$[163,168]$} \\
\hline & $142 a$ & $-\mathrm{O}-\mathrm{C}_{6} \mathrm{H}_{4}\left(4-\mathrm{NHCOCH}_{3}\right)$ & {$[163,178]$} \\
\hline & 143a & $-\mathrm{COCF}_{3}$ & [163] \\
\hline & $144 a$ & $-\mathrm{Cl}$ & [163] \\
\hline & 145a & $-\mathrm{Br}$ & [163] \\
\hline & $146 a$ & $-\mathrm{SCH}_{3}$ & [163] \\
\hline & $147 a$ & $-\mathrm{SC}_{6} \mathrm{H}_{4}(4-\mathrm{Cl})$ & [163] \\
\hline & 148a & $-\mathrm{SC}_{6} \mathrm{H}_{4}(3-\mathrm{Cl})$ & [163] \\
\hline & 149a & $-\mathrm{SC}_{6} \mathrm{H}_{4}(2-\mathrm{Cl})$ & [163] \\
\hline & 150a & $-\mathrm{SC}_{6} \mathrm{H}_{3}\left(3,4-\mathrm{Cl}_{2}\right)$ & [163] \\
\hline & $151 a$ & $-\mathrm{SC}_{6} \mathrm{H}_{3}\left(2,5-\mathrm{Cl}_{2}\right)$ & [163] \\
\hline & $152 a$ & $-\mathrm{SC}_{6} \mathrm{H}_{3}\left(3-\mathrm{CF}_{3}\right)$ & [163] \\
\hline & 153a & $-\mathrm{S}-\mathrm{C}_{10} \mathrm{H}_{7}$ & [163] \\
\hline & $154 a$ & $-\mathrm{NH}-\mathrm{C}_{6} \mathrm{H}_{4}\left(3-\mathrm{CF}_{3}\right)$ & [163] \\
\hline & 155a & $-\mathrm{N}\left(\mathrm{CH}_{3}\right)_{2}$ & [163] \\
\hline & 156a & $-\mathrm{O}-\mathrm{C}_{6} \mathrm{H}_{4}\left(4-\mathrm{OCF}_{3}\right)$ & [168] \\
\hline & 157a & $-\mathrm{O}-\mathrm{C}_{6} \mathrm{H}_{4}\left(4-\mathrm{OCH}_{3}\right)$ & {$[168]$} \\
\hline & 158a & $-\mathrm{O}-\mathrm{C}_{6} \mathrm{H}_{3}\left(2,4-\mathrm{Cl}_{2}\right)$ & {$[168]$} \\
\hline & 159a & $-\mathrm{O}-\mathrm{C}_{6} \mathrm{H}_{3}\left(3,4-\mathrm{Cl}_{2}\right)$ & [168] \\
\hline & $160 a$ & $-\mathrm{O}-\mathrm{C}_{6} \mathrm{H}_{3}\left(3,5-\left(\mathrm{CF}_{3}\right)_{2}\right)$ & [168] \\
\hline & 161a & $-\mathrm{O}-\mathrm{C}_{6} \mathrm{H}_{3}\left(3-\mathrm{CF}_{3}, 4-\mathrm{F}\right)$ & [168] \\
\hline & $162 a$ & $-\mathrm{OPh}$ & [168] \\
\hline & 163a & $-\mathrm{C}_{2} \mathrm{H}_{5}$ & {$[174]$} \\
\hline & $164 a$ & $-n-\mathrm{C}_{3} \mathrm{H}_{7}$ & [174] \\
\hline & 165a & $-n-\mathrm{C}_{4} \mathrm{H}_{9}$ & [174] \\
\hline & $166 a$ & $-n-\mathrm{C}_{5} \mathrm{H}_{11}$ & [174] \\
\hline & $167 a$ & $-n-\mathrm{C}_{6} \mathrm{H}_{13}$ & [174] \\
\hline & $168 a$ & $-n-\mathrm{C}_{8} \mathrm{H}_{17}$ & {$[174]$} \\
\hline & 169a & $-n-\mathrm{C}_{10} \mathrm{H}_{21}$ & [174] \\
\hline & 170a & $-\mathrm{OH}$ & [179] \\
\hline 7 & 171a & $-\mathrm{CH}_{3}$ & [163] \\
\hline
\end{tabular}

mechanism involving the C-2 of the quinolinic ring [164]. Moreover, the anti-malarial activity of 2-tert-butylprimaquine was demonstrated against $P$. berghei, Plasmodium yoelii nigeriensis (in vivo) and $P$. falciparum (in vitro), exhibiting attributes of a new potent blood-schizontocidal. These are remarkable findings, as PQ itself is not a blood-schizontocide [165]. A latest report upholds that the remarkable blood-schizontocidal activity of 2-tert-butylprimaquine may be due to a disturbance of the heme catabolism pathways in the malarial parasite. Such effect would be similar to what occurs with CQ i.e., inhibition of heme crystallization through formation of a drug-heme complex, preventing clearance of hemeassociated toxicity from the parasite [166]. These were also presented by Jain et al. studies involving several 8AQ compounds obtained by insertion of substituents at the quinolinic ring of PQ [167], where 4-ethyl-5-pentyloxyprimaquine has also displayed promising results [51].

Overall, it seems that insertion of an appropriate substituent at the quinoline's carbon 2 leads to a small improvement in antimalarial activity along with a decrease in general systemic toxicity. In contrast, introduction of a methyl group at C-4 increases therapeutic activity, but at the expense of greater toxicity, as concluded from multiple-dose studies.

The presence of a phenoxy substituent on C-5 decreases toxicity while maintaining or improving activity. Further efforts that are focused on combinations of different substitutions on the quinoline moiety have almost invariably contributed to establish the above as key modifications towards a good activity/toxicity balance, with other modifications being less important or only useful for a fine tuning of the overall compound performance [96].

\subsection{Modifications at the terminal primary amine}

Blocking the terminal primary amine in PQ may represent a huge improvement in terms of $\mathrm{PQ}$ bioavailability, as it can significantly reduce the extent of $\mathrm{PQ}$ conversion into carboxyprimaquine. $\mathrm{N}$-Acylation of anti-malarials with amino acids and oligopeptides has been used in several works aimed at improving drug transport into malaria-infected erythrocytes and, over the last two decades, these modifications started to be also seen as a means to avoid premature $\mathrm{PQ}$ inactivation by oxidative deamination to carboxyprimaquine [180]. An earlier work describes the synthesis of $\mathrm{N}$-cysteinyl-primaquine that was subsequently coupled to carrier proteins, and both the anti-malarial activity in vivo and the acute lethal toxicity of the protein-drug conjugates were evaluated. The causal prophylactic activity of the lactosaminated serum albumin conjugate was two times higher than that of the free drug, whereas its acute lethal toxicity was at least 6.5-fold lower than that of PQ [mean lethal dose (LD50) $>85 \mathrm{mg}$ of PQ base $/ \mathrm{kg}$ ]. This yielded a therapeutic index for the conjugate at least 12 times higher than that of the free parent drug [181].

Oligopeptide derivatives of PQ such as PQ-Lys-Leu-D-Val, PQLys-Leu-Ala and PQ-Lys-Leu-L-Val have been prepared and tested for radical curative anti-malarial activity against $P$. cynomolgi in rhesus monkeys and blood-schizontocidal activity against $P$. berghei in mice. The $\mathrm{D}-\mathrm{Val}$-containing derivative was found to be less toxic and more active than both its L-Val counterpart and $\mathrm{PQ}$, whereas the activity of the Ala-bearing compound was comparable to that of the $\mathrm{L}-\mathrm{Val}$ derivative [182].

PQ $N$-acylation with amino acids or oligopeptides yields structures that are amenable to suffer proteolytic degradation; despite this biorreversibility being desirable in a prodrug, fast conversion into PQ will not allow overcoming the problems associated with PQ-based therapies. Thus, additional protection of the peptide moiety in peptidyl-PQ compounds became a new goal, so that structures could be obtained with (i) resistance to early proteolytic cleavage, and (ii) biorreversibility at target tissues or cells in order to release the active molecule [183].

Borissova et al. synthesized two groups of tetrapeptides with general formula PQ-Y-Ala-Leu-X-NH 2 . In the first group, Leu, Tyr, Lys and Asp were used in the $\mathrm{Y}$ positions, while $\mathrm{X}$ was Ala. In the second group, Ala, Tyr, Lys and Asp were used in $X$ positions, while $Y$ was Leu. All the peptide derivatives were then coupled to polyacryl starch microparticles (via the $N$-terminal amino acid $\alpha$ amino group), forming lysosomotropic drug carriers [184]. The same authors studied the importance of enzymes, other than aminopeptidases, during lysosomal degradation of these conjugates, concluding that the latter are substrates for mono-, diamino- and endopeptidases, whereas PQ could not be directly cleaved by the action of any carboxypeptidase-like enzymes [185].

Dipeptide derivatives of PQ (PQ-Arg-Phe, PQ-Arg-Lys and PQAla-Phe) were also synthesized and tested against Chagas disease. PQ-Arg-Lys was seen to be active against $T$. cruzi development inside host cells, probably by interfering with the initial steps of trypomastigote-amastigote transformation. This derivative was more active than the other two, so it seems that specific cleavage has an important role in PQ release [186].

Portela et al. have also evaluated the dipeptide derivatives of $\mathrm{PQ}$ as novel transmission-blocking anti-malarials. In contrast with PQ none of the compounds were able to block oocyst production in mosquitoes' midguts at $3.75 \mathrm{mg} / \mathrm{kg}$, but all of them were found to completely inhibit the formation of oocysts at $15 \mathrm{mg} / \mathrm{kg}$, whereas $\mathrm{N}$-acetylprimaquine is not active at this dose. As a whole, this work has demonstrated that acylation of the PQ's primary amino group effectively prevents the early conversion of $\mathrm{PQ}$ into carboxyprimaquine, while confirming that the presence of a terminal 
amino group, as in the dipeptide derivatives of $\mathrm{PQ}$ is essential for gametocytocidal activity [187].

Recently, Gomes et al. worked on the further transformation of the amino acid moiety linked to the PQ's primary amine, upon introduction of an imidazolidin-4-one ring at the amino acid's $\alpha$ amino group (30). Condensation of the $N$-aminoacyl derivatives of PQ with carbonyl compounds (ketones or aldehydes) was seen by these authors as a means to protect the amino acid moiety against premature proteolytic degradation $[188,189]$.

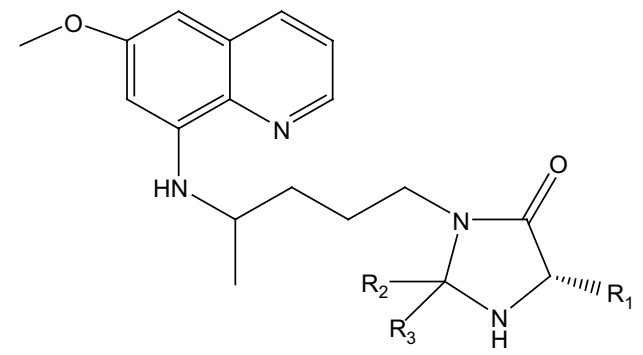

30 a weak or null degree of PQ release after 3 days of incubation. Moreover, compound 30 hydrolyzed 50-100 times slower in aqueous buffer at physiological $\mathrm{pH}$ and $T$ than the corresponding imidazolidin-4-ones derived from di- and penta-peptides [190,191]. These imidazolidin-4-ones (30) were effective in preventing $P$. berghei malaria transmission from BalbC mice to Anopheles stephensi mosquitoes [190,192]. Most of these compounds were also active against Pneumocystis carinii above $10 \mu \mathrm{g} / \mathrm{mL}$, which was correlated to their anti-P. falciparum blood-schizontocidal activity in vitro [193]. A latest report from the same authors accounts for the synthesis and biological activity of $N^{1}$-aminoacyl derivatives of 30 as mimetics of PQProXaa structures (where Xaa stands for a general amino acid linked to proline that, in turn, is linked to the parent drug). Such structures were again found to be remarkably stable, modestly active as a blood-schizontocidal against a CQ-resistant strain of $P$. falciparum and effective inhibitors of the sporogonic cycle of $P$. berghei in A. stephensi mosquitoes [194].

Another example of PQ modification at its primary amino group concerns its linkage to statine-based inhibitors of Plasmepsin II (PLM II), aiming at the development of 'double-drugs'. PLM II is one of the aspartate proteases involved in the degradation of hemoglobin during the intra-erythrocytic cycle of $P$. falciparum. Results in vitro have shown the above approach to constitute an improvement compared to other statine-based PLM II inhibitors [195].

The development of PQ prodrugs based on PQ modification at its $\mathrm{N}$-terminus has also been invoked in a work where succinylprimaquine and maleylprimaquine derivatives were prepared and submitted to electrochemical studies. Molecular modification contributed to facilitate the drug electro-oxidation, but no biological assays of these potential prodrugs have been described [196].

Novel PQ derivatives of $\mathrm{N}$-alkyl-, cycloalkyl- or aryl-urea were also prepared by aminolysis of benzotriazolide with the corresponding amines. The pyridine derivative exhibited the best cytostatic activities against colon carcinoma, human T-lymphocytes and murine leukemia, showing also rather marked cytotoxicity towards human normal fibroblasts. Results of broad antiviral evaluation showed that pyridine and phenethyl derivatives of urea exhibited some selective inhibition against cytomegalovirus [197].

PQ derivatives 31 were designed and synthesized by Zhu and coworkers, who found these compounds to have lower toxicity than

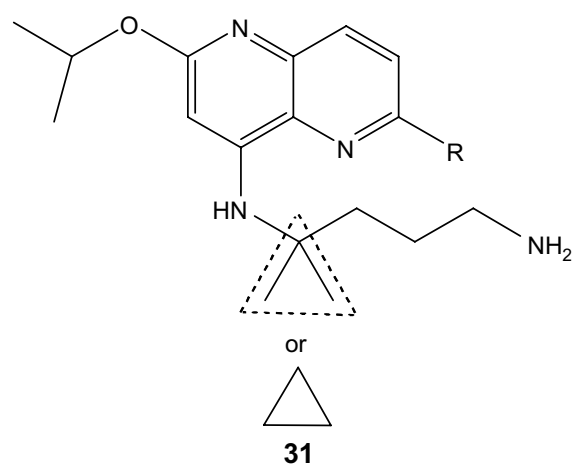

$\mathrm{PQ}$, due to a reduced tendency to produce chemically reactive toxic metabolites and metabolic intermediates [198]. Some of the compounds possessed therapeutic indices over 10 times superior to that of CQ [198].

\subsection{PQ analogues in preclinical or clinical assays}

Both types of PQ modification, i.e., insertion of substituents at the quinoline ring and modification of the terminal primary amino group, gave rise to the discovery of highly promising drugs $[199,200]$. In this connection, this last section will be devoted to three PQ derivatives that, given their excellent therapeutic prospects, are now under transition to (NPC 1161C, 32) or already in advanced phases of clinical assays (bulaquine or elubaquine, 33; tafenoquine, 34) [160] as anti-malarials, and sitamaquine (35) as a leishmanicidal and anti-Pneumocystis agent.

\subsubsection{NPC $1161 C$ (32)}

The scaffold of this compound was synthesized in the early 1980s [172], but only 10 years later was the final succinate salt obtained. NPC $1161 \mathrm{C}$ is seen as a very promising anti-malarial candidate due to its in vivo oral potency in mice, activity against both blood and tissue stage parasites, favourable toxicity profile, long-term action, and utility in both prophylaxis and treatment models. Metabolites are now being investigated so that physicochemical and pharmaceutical profiles can be improved [201,202].

Recent data indicate that NPC1161B (the (-)-enantiomer) shows great potential as a new $8 \mathrm{AQ}$ drug with limited toxicity and enhanced efficacy, as compared to those currently in use or under development, for the treatment of several parasitic infections [95].

\subsubsection{Bulaquine or aablaquine (33)}

Bulaquine (CDRI 80/53) is a potent anti-malarial PQ analogue developed at the Central Drug Research Institute - CDRI - of India [203-209]. After 7 days of PQ administration, methemoglobin levels increase from $3.97 \%$ to $16.32 \%$, whereas bulaquine-induced levels under identical conditions range between $2.29 \%$ and $3.02 \%$. Moreover, the extent of hemolysis in G6PD-deficient individuals caused by bulaquine is not as high as that verified for PQ [160,204,205].

The pharmacokinetic profile of bulaquine was investigated in rhesus monkeys infected with $P$. cynomolgi $\mathrm{B}$., against which the drug has proven gametocytocidal efficacy. Twenty-four hours after a single administration of bulaquine at $1.25 \mathrm{mg} / \mathrm{kg}$, oocyst development was fully blocked, so the disease was not transmitted to $A$. stephensi mosquitoes fed on the infected monkeys' blood. A similar effect is observed $5 \mathrm{~h}$ after administration of a single $3.75 \mathrm{mg} / \mathrm{kg}$ dose. These results show that bulaquine is more potent and exerts its gametocytocidal activity faster than PQ [209]. 
Given the high profile of bulaquine, this drug has been further studied in clinical assays. Phase II studies were carried out on $697 \mathrm{P}$. vivax-infected patients. These studies have shown similar patterns of relapse for oral administration, during 5 days, of bulaquine at $25 \mathrm{mg} /$ day and of PQ at $15 \mathrm{mg} /$ day, with the advantage falling on bulaquine due to its lower toxicity $[160,205]$.

Despite some preclinical pilot pharmacokinetic studies in rats, rabbits and monkeys have been described as applications to the validation procedures [206,208,210-213], no report has been published to date concerning the complete in vivo pharmacokinetic profile of bulaquine in various species and linking it to in vitro studies. Recently, Mehrotra et al. suggested that in vitro protein binding and red blood cell (RBC) uptake studies should be carried out at around systemic concentrations obtained from in vivo studies, so that a realistic insight into the pharmacokinetics of the drug candidate could be obtained [214].<smiles>COc1ccc2c(Oc3ccc(Cl)c(Cl)c3)c(OC)cc(NC(C)CCC[NH3+])c2n1</smiles>

\subsubsection{Tafenoquine (34)}

Tafenoquine was firstly used in an US Army programme as a substitute for PQ and was found to be more effective on radical cure of vivax malaria relapses, yet did not receive too much attention by then. This picture changed radically once tafenoquine's potent blood-schizontocidal activity against multidrugresistant asexual blood stages of $P$. falciparum was identified, leading to reinforcement of preclinical development [4]. When given orally, tafenoquine is slowly absorbed and metabolized, in contrast to PQ having a $t_{\max }$ of $12 \mathrm{~h}$ and an elimination half-life of 14 days [215]. This unmistakably turned tafenoquine to be the most serious candidate to substitute PQ in clinics in the near future.

An early report revealed the treatment of two acute cases of malaria with tafenoquine alone ( $800 \mathrm{mg} /$ day over 3 days), instead of the conventional combination of chloroquine $(1500 \mathrm{mg} /$ day over 3 days) with PQ (420 mg/day over 14 days) [216].

The prophylactic efficacy of tafenoquine was studied in a human $P$. falciparum challenge model. After administration of a single $600 \mathrm{mg}$ oral dose, tafenoquine successfully prevented $P$. falciparum malaria in 3 of 4 non-immune volunteers [217]. Data obtained in vitro also revealed that some $8 \mathrm{AQ}$ derivatives, among which was tafenoquine, are active against intra-erythrocytic forms of the parasite, acting through inhibition of hematin polymerization [218].

The promising performance of tafenoquine gave rise to a number of additional studies, some of them devoted to explore different dosages and involve higher numbers of individuals, others to investigate the effects of combining tafenoquine with other anti- malarials [219-221]. Those studies support that tafenoquine has the potential to be used in a variety of situations beyond that of chemoprophylaxis [222]. Monthly tafenoquine was safe, welltolerated, and highly effective in preventing $P$. vivax and multidrugresistant $P$. falciparum malaria in Thai soldiers during 6 months of prophylaxis [223]. The pharmacokinetics of tafenoquine orally administered to Thai soldiers has been explored, and the drug demonstrated as both a useful prophylactic drug or for short-term radical treatment of vivax malaria [224]. Additionally, the drug was well-tolerated by the patients, being occasionally associated only to mild gastrointestinal effects [225].

Presently, research focus is being directed towards combinations of tafenoquine with other drugs, namely with CQ. This combined therapy, administered over 8 weeks, is apparently more effective than 'CP' tablets (with PQ at a dose of $22.5 \mathrm{mg} /$ day) in preventing further $P$. vivax relapses [226].<smiles>COc1cc(NC(C)CCCN/C(C)=C2\CCOC2=O)c2ncccc2c1</smiles>

Ramharter et al. [221] have also found that the tafenoquineartemisinine combination was synergistic in vitro, so this combination may become an excellent way of treating multidrug-resistant falciparum malaria.

In view of all the above, tafenoquine really appears to be a most serious candidate to find its place on the Pharmaceutist's shelves. However, potential side effects of tafenoquine, such as methemoglobinemia and the risk of hemolysis in 6GPD-deficient patients, have to be fully evaluated [227].

\subsubsection{Sitamaquine or WR6026 (35)}

Sitamaquine is an 8AQ analogue of PQ that is being developed for the treatment of visceral leishmaniasis and pneumocystic pneumonia [228]. This drug is already in clinical assays for the oral treatment of visceral leishmaniasis [41], with phase II trials in India and Kenya being quite encouraging [229,230]. Physicochemical analysis of the interaction of sitamaquine with phospholipid monolayers and sterols at the air-water interface showed interactions only to occur in the presence of anionic phospholipids. Thus, electrostatic interactions between the positively charged drug and the negatively charged headgroups seem to be the initial step of drug interaction with the protozoan cell surface, after which hydrophobic interactions between the drug's aromatic ring and the phospholipid's inner core of alkyl chains take place, leading to drug insertion [43]. So it seems that sitamaquine exerts its anti-protozoan action in a fashion similar to that of antimicrobial peptides, many of them also reported as promising leishmanicidal agents [231-233]. 
<smiles>COc1ccc2c(Oc3cccc(C(F)(F)F)c3)c(OC)cc(NC([14CH3])CCCN)c2n1</smiles>

34<smiles>CCN(CC)CCCCCCNc1cc(OC)cc2c(C)cc(OC)nc12</smiles>

35

\section{Final remarks}

Primaquine may not be the anti-malarial drug with the best therapeutic profiles [121,234], and several aspects of its biological action are yet to be discovered. However, primaquine is still the only transmission-blocking anti-malarial clinically useful and it goes on being used as the platform for developing novel anti-malarials with improved efficacy and reduced toxicity [21]. Good safety, tolerance and efficacy, along with key advantages in dosing requirements, make PQ an excellent drug for preventing malaria in non-pregnant, G6PD-normal travellers [235,236]. This will certainly lead, in a near future, to a totally safe and highly active PQ derivative or analogue to be used against malaria and other parasitic diseases. Being malaria the top-priority tropical disease for the WHO and a major global health concern, support must be given to scientists from any research field who are devoted to the fight against this disease. From Medicinal Chemists searching for novel compounds to Molecular Biologists unveiling the complex meanders of the parasite's lifecycle, all have a valuable contribution to give, if they are supplied the necessary resources. For instance, new chemotherapy strategies can be now devised after the recent discovery that gametogenesis in malaria parasites is mediated by PKG, a cGMP-dependent protein kinase [237]. The costs inherent to this type of research and to the subsequent efforts towards novel drugs are considerable and a number of projects have only succeeded due to public-private partnerships and due to the generosity of philanthropic organizations such as Wellcome, The Rockefeller Foundation, and the Bill and Melinda Gates Foundation [238].

\section{Acknowledgments}

Thanks are due to FCT (Fundação para a Ciência e Tecnologia, Portugal) for funding through project PTDC/QUI/65142/2006. NV thanks FCT for Ph.D. grant SFRH/BD/17754/2004. PG and RM thank FCT for financial support to CIQUP and CECF, respectively.

\section{References}

[1] R. Pink, A. Hudson, M.A. Mouriès, M. Bending, Nat. Rev. Drug Discov. 4 (2005) 727-740.

[2] S.I. Hay, C.A. Guerra, A.J. Tatem, A.M. Noor, R.W. Snow, Lancet Infect. Dis. 4 (2004) 327-336

[3] <http://wrair-www.army.mil/>.

[4] W. Peters, J. R. Soc. Med 92 (1999) 345-352.

[5] J. Wiesner, R. Ortmann, H. Jomaa, M. Schlitzer, Angew. Chem., Int. Ed. 42 (2003) 5274-5293.

[6] R.C. Elderfield, H.E. Mertel, R.T. Mitch, I.M. Wempen, E. Werble, J. Am. Chem. Soc. 77 (1955) 4816-4819.

[7] A.S. Alving, B. Craige Jr., R. Jones Jr., C.M. Whorton, T.N. Pullman, L. Eichelberger, J. Clin. Invest. 27 (1948) 25-33.
[8] R.C. Elderfield, E.F. Claflin, H.E. Mertel, O.L. McCurdy, R.T. Mitch, C.D.N. Nooy, B.H. Wark, I.M. Wempen, J. Am. Chem. Soc. 77 (1955) 4819-4822.

[9] K.J. Baird, S.L. Hoffman, Clin. Infect. Dis. 39 (2004) 1336-1345.

[10] J. Ducharme, R. Farinotti, Clin. Pharmacokinet. 31 (1996) 257-274.

[11] <http://www.who.int/en/>.

[12] J.N. Domínguez, Curr. Top. Med. Chem. 2 (2002) 1173-1185.

[13] P.J. Rosenthal, J. Exp. Biol. 206 (2003) 3735-3744.

[14] D.R. Hill, J.K. Baird, M.E. Parise, L.S. Lewis, E.T. Ryan, A.J. Magill, Am. J. Trop. Med. Hyg. 75 (2006) 402-415

[15] J.K. Baird, N. Engl. J. Med. 352 (2005) 1565-1577.

[16] D. Bell, P. Winstanley, Br. Med. Bull. 71 (2004) 29-43.

[17] F. Nosten, R. McGready, U. d'Alessandro, A. Bonell, F. Verhoeff, C. Menendez, T. Mutabingwa, B. Brabin, Curr. Drug Saf. 1 (2006) 1-15.

[18] J.S. Kim, J.S. Oh, E.A. Chang, S.Y. Bae, D.H. Nam, C.H. Lee, J.H. Yang, C.K. Lee, W.J. Lee, H.C. Kim, T.A. Klein, C.S. Lim, Y.K. Kim, Acta Trop. 106 (2008) 39-43.

[19] E. Schwartz, G.R. Yochay, Clin. Infect. Dis. 29 (1999) 1502-1506.

[20] D.D. Rajgor, N.J. Gogtay, V.S. Kadam, K.D. Kamtekar, S.S. Dalvi, A.R. Chogle, U. Aigal, L.S. Bichile, K.C. Kain, N.A. Kshirsagar, Trans. R. Soc. Trop. Med. Hyg. 97 (2003) 438-440.

[21] D.J. Fryauff, A.L. Richards, J.K. Baird, T.L. Richie, E. Mouzin, E. Tjitra, M.A. Sutamihardja, S. Ratiwayanto, H. Hadiputranto, R.P. Larassati, N. Pudjoprawoto, B. Subianto, S.L. Hoffman, Antimicrob. Agents Chemother. 40 (1996) 2737-2742.

[22] E. Schwartz, G.R. Yochay, D. Kurnik, Am. J. Trop. Med. Hyg. 62 (2000) 393395.

[23] J.M. Spudick, L.S. Garcia, D.M. Graham, D.A. Haake, J. Clin. Microbiol. 43 (2005) 978-981.

[24] J.K. Baird, K.H. Rieckmann, Trends Parasitol. 19 (2003) 115-120.

[25] S. Noel, S. Sharma, R. Shanker, S.K. Rath, Toxicology 239 (2007) 96-107.

[26] P. Mayorga, F. Puisieux, G. Couarraze, Int. J. Pharm. 132 (1996) 71-79.

[27] C.M. Heard, B.V. Monk, A.J. Modley, Int. J. Pharm. 257 (2003) 237-244.

[28] D. Bhadra, A.K. Yadav, S. Bhadra, N.K. Jain, Int. J. Pharm. 295 (2005) 221-233.

[29] K.K. Nishi, A. Jayakrishnan, Biomacromolecules 5 (2004) 1489-1495.

[30] K.K. Nishi, A. Jayakrishnan, Biomacromolecules 8 (2007) 84-90.

[31] M.D. Green, M.J. D'Souza, J.M. Holbrook, R.A. Wirtz, J. Microencapsul. 21 (2004) 433-444.

[32] J.M. Rodrigues Jr., H. Fessi, C. Bories, F. Puisieux, J.P. Devissaguet, Int. J. Pharm. 126 (1995) 253-260.

[33] K.K. Singh, S.K. Vingkar, Int. J. Pharm. 347 (2008) 136-143.

[34] G. Stensrud, S.A. Sande, S. Kristensen, G. Smistad, Int. J. Pharm. 198 (2000) 213-228.

[35] A.M. Dierling, Z. Cui, Int. J. Pharm. 303 (2005) 143-152.

[36] <http://www.merck.com.mmpe/index.html>.

[37] F.J. Vilar, K.T. Walley, Br. J. Clin. Pharmacol. 47 (1999) 605-609.

[38] K. Teruya, A. yasuoka, M. Yamaguchi, C. Yasuoka, Y. Yamamoto, I. Genka, N. Tachikawa, Y. Kikuchi, S. Oka, Intern. Med. 40 (2001) 221-226.

[39] A.G. Smulian, Fungal Genet. Biol. 34 (2001) 145-154.

[40] S.F. Queener, J. Med. Chem. 38 (1995) 4739-4759.

[41] S.F. Queener, M.S. Bartlett, J.D. Richardson, M.M. Durkin, M.A. Jay, J.W. Smith, Antimicrob. Agents Chemother. 32 (1988) 807-813.

[42] M.S. Bartlett, S.F. Queener, R.R. Tidwell, W.K. Milhous, J.D. Berman, W.Y. Ellis, J.W. Smith, Antimicrob. Agents Chemother. 35 (1991) 277-282.

[43] S.F. Queener, M.S. Bartlett, M. Nasr, J.W. Smith, Antimicrob. Agents Chemother. 37 (1993) 2166-2172.

[44] A. Wilkin, J. Feinberg, Am. Fam. Physician 60 (1999) 1699-1714.

[45] M.D. Ball, M.S. Bartlett, M. Swaw, J.W. Smith, M. Nasr, S.R. Meshnick, Antimicrob. Agents Chemother. 45 (2001) 1473-1479.

[46] T.E. Goodwin, C.J. Boylan, W.L. Current, J.C. Byrd, C.B. Edwards, D.A. Fuller, J.L. Green, C.D. Larocca, K.D. Raney, A.S. Ross, W.A. Tucker, Bioorg. Med. Chem. Lett. 10 (2000) 2205-2208.

[47] G.A. Noskin, R.L. Murphy, J.R. Black, J.P. Phair, Clin. Infect. Dis. 14 (1992) 183-188. 
[48] J.J.V. Eynde, A. Mayence, T.L. Huang, M.S. Collins, S. Rebholz, P.D. Walzer, M.T. Cushion, Bioorg. Med. Chem. Lett. 14 (2004) 4545-4548.

[49] P.J. Guerin, P. Olliaro, S. Sundar, M. Boelaert, S.L. Croft, P. Desjeux, M.K. Wasunna, A.D.M. Bryceson, Lancet Infect. Dis. 2 (2002) 494-501.

[50] J.D. Berman, L.S. Lee, Am. J. Trop. Med. Hyg. 32 (1983) 753-759.

[51] K. Kaur, S.R. Patel, P. Patil, M. Jain, S.I. Khan, M.R. Jacob, S. Ganesan, B.L. Tekwani, R. Jain, Bioorg. Med. Chem. 15 (2007) 915-930.

[52] G. Banerjee, S. Medda, M.K. Basu, Antimicrob. Agents Chemother. 42 (1998) 348-351.

[53] A. Nan, N.P.D. Nanayakkara, L.A. Walker, V. Yardley, S.L. Croft, H. Ghandehari, J. Control. Release 77 (2001) 233-243.

[54] R. Dietze, S.F.G. Carvalho, L.C. Valli, J. Berman, T. Brewer, W. Milhous, J. Sanchez, B. Schuster, M. Grogl, Am. J. Trop. Med. Hyg. 65 (2001) 685-689.

[55] J.R. Rashid, P.M. Nyakundi, G. Kirigi, D. Kinoti, M.K. Wasunna, Trans. R. Soc. Trop. Med. Hyg. 96 (2002) 533-534.

[56] A.M.D. Romero, P.M. Loiseau, M.S.P. Chazalet, Biochem. Biophys. Acta 1768 (2007) 246-252.

[57] H.M. Sousa, G.M. Pianetti, O.C. Oliveira, P. Barretto, K. Nonoyama, M. Grol, E. Chiari, Rev. Soc. Bras. Med. Trop. 35 (2002) 563-569.

[58] K.E. Kinnamon, E.A. Steck, J. Med. Chem. 20 (1977) 741-744.

[59] M.A. La-Scalea, C.M. Chin, M.L. Cruz, S.H.P. Serrano, E.I. Ferreira, Bioelectrochemistry 53 (2000) 55-59.

[60] L.J. Goad, R.L. Berens, J.J. Marr, D.H. Beach, G.G. Holz Jr., Mol. Biochem. Parasitol. 32 (1989) 179-189.

[61] R.E. McCabe, J. Parasitol. 74 (1988) 748-753.

[62] J.R. Burdick, D.P. Durand, Antimicrob. Agents Chemother. 6 (1974) 460-464.

[63] T. Matsuno, F. Hariguchi, T. Okamoto, J. Vet. Med. Sci. 53 (1991) 13-17.

[64] R.E. Armer, J.S. Barlow, C.J. Dutton, D.H.J. Greenway, S.D.W. Greenwood, N. Lad, I. Tommasini, Bioorg. Med. Chem. Lett. 7 (1997) 2585-2588.

[65] R.E. Armer, J.S. Barlow, C.J. Dutton, D.H.J. Greenway, S.D.W. Greenwood, N. Lad, A.P. Thompson, K.W. Thong, I. Tommasini, Bioorg. Med. Chem. Lett. 8 (1998) 1487-1492.

[66] N.J. White, P.L. Olliaro, Parasitol. Today 12 (1996) 399-401.

[67] W. Peters, L.B. Stewart, B.L. Robinson, Ann. Trop. Med. Parasitol. 97 (2003) 221-236.

[68] E.R. Lederman, J.D. Maguire, I.W. Sumawinata, K. Chand, I. Elyazar, L. Estiana, P. Sismadi, M.J. Bangs, J.K. Baird, Malar. J. 5 (2006) 108-117.

[69] P.G. Bray, S. Deed, E. Fox, M. Kalkanidis, M. Mungthin, L.W. Deady, L. Tilley, Biochem. Pharmacol. 70 (2005) 1158-1166.

[70] T.J. Egan, Trends Parasitol. 22 (2006) 235-237.

[71] L.H. Schmidt, Antimicrob. Agents Chemother. 27 (1985) 151-157.

[72] P.T. Giao, P.J. Vries, Clin. Pharmacokinet. 40 (2001) 343-373.

[73] S. Pukrittayakamee, K. Chotivanich, A. Chantra, R. Clemens, S. Looareesuwan, N. White, Antimicrob. Agents Chemother. 48 (2004) 1329-1334.

[74] U. Silachamroon, S. Krudsood, S. Treeprasertsuk, P. Wilairatana, K. Chalearmrult, H.Y. Mint, P. Maneekan, N.J. White, V.R. Gourdeuk, G.M. Brittenham, S. Looareesuwan, Am. J. Trop. Med. Hyg. 69 (2003) 14-18.

[75] P.H. Schlesinger, D.J. Krogstad, B.L. Herwaldt, Antimicrob. Agents Chemother 32 (1988) 793-798.

[76] B.L. Tekwani, L.A. Walker, Curr. Opin. Infect. Dis. 19 (2006) 623-631.

[77] S. Krishna, N.J. White, Clin. Pharmacokinet. 30 (1996) 263-299.

[78] M. Mungthin, P.G. Bray, R.G. Ridley, S.A. Ward, Antimicrob. Agents Chemother. 42 (1998) 2973-2977.

[79] A. Adedoyin, R. Frye, K. Mauro, R.A. Branch, Br. J. Clin. Pharmacol. 46 (1998) 215-219.

[80] M. Henry, S. Alibert, E. Orlandi-Pradines, H. Bogreau, T. Fusai, C. Rogier, J. Barbe, B. Pradines, Curr. Drug Targets 7 (2006) 935-948.

[81] N. Lang-Unnasch, A.D. Murphy, Annu. Rev. Microbiol. 52 (1998) 561-590.

[82] M. Chutmongkonkul, W.A. Maier, H.M. Steitz, Ann. Trop. Med. Parasitol. 86 (1992) 207-215

[83] R.E. Sindem, M.E. Smalley, Parasitology 79 (1979) 277-296.

[84] M. Aikawa, R.L. Beaudoin, Exp. Parasitol. 27 (1970) 454-463.

[85] R.L. Beaudoin, M. Aikawa, Science 160 (1968) 1233-1234.

[86] Y. Boulard, I. Laudau, F. Miltgen, D.S. Ellis, W. Peters, Ann. Trop. Med. Parasitol. 77 (1983) 555-568.

[87] R.E. Howells, W. Peters, J. Fullard, Ann. Trop. Med. Parasitol. 64 (1970) 203207.

[88] N. Lanners, Parasitol. Res. 77 (1991) 478-481.

[89] K.K. Baird, G.J. Mccormick, C.J. Caufield, Biochem. Pharmacol. 35 (1986) 1099-1106.

[90] W. Peters, S.G. Irare, D.S. Ellis, D.C. Warhurst, B.L. Robinson, Ann. Trop. Med. Parasitol. 78 (1984) 567-579.

[91] A. Rotman, J. Gen. Microbiol. 89 (1975) 1-10.

[92] M.D. Bates, S.R. Meshnick, C.I. Sigler, P. Leland, M.R. Hollingdale, Am. J. Trop. Med. Hyg. 42 (1990) 532-537.

[93] N.P.D. Nanayakkara, A.L. Ager Jr., M.S. Bartlett, V. Yardley, S.L. Croft, I.A. Khan, J.D. McChesney, A.L. Walker, Antimicrob. Agents Chemother. 52 (2008) 21302137.

[94] R.P. Brueckner, C. Ohrt, J.K. Baird, W.K. Milhous, 8-Aminoquinolines, in P.J. Rosenthal (Ed.), Antimalarial chemotherapy: mechanisms of action, resistance and new directions in drug discovery, Humana Press, Totowa, N.J., 2001, pp. 123-151.

[95] T.E. Bapiro, T.B. Andersson, C. Otter, J.A. Hasler, C.M. Masimirembwa, Eur. J. Clin. Pharmacol. 58 (2002) 537-542.

[96] J.G. Olenick, F.E. Hahn, Antimicrob. Agents Chemother. 1 (1972) 259-262.

[97] J.G. Olenick, Antimicrob. Agents Chemother. 8 (1975) 754-756.
[98] L.H. Schmidt, S. Alexander, L. Allen, J. Rasco, Antimicrob. Agents Chemother 12 (1977) 51-60.

[99] J.K. Baker, J.D. McChesney, J. Pharm. Sci. 77 (1988) 380-382.

[100] S. Agarwal, U.R. Gupta, R.C. Gupta, N. Anand, S.S. Agarwal, Biochem. Pharmacol. 37 (1988) 4605-4609.

[101] P. Mayorga, E. Deharo, F. Puisieux, G. Couarrage, Int. J. Pharm. 155 (1997) 99-107.

[102] C.W. Jeans, C.M. Heard, Int. J. Pharm. 189 (1999) 1-6.

[103] D.R. Brocks, R. Mehvar, Clin. Pharmacokinet. 42 (2003) 1359-1382.

[104] B. Somasundaram, J.C. Norman, M.P.M. Smith, Biochem. J. 309 (1995) 725-729.

[105] R.B. Gregory, G.J. Barritt, Biochem. J. 319 (1996) 755-760.

[106] G.O. Salazar, R.A. Bouchard, F.M. Salgado, E.M.S. Stefanon, Br. J. Pharmacol 135 (2002) 751-763.

[107] R.R. Hiebsch, T.J. Raub, B.W. Wattenberg, J. Biol. Chem. 266 (1991) 20323 20328.

[108] W.M. Weber, A. Segal, A. Vankeerberghen, J.J. Cassiman, W.V. Driessche Comp. Biochem. Physiol. A 130 (2001) 521-531.

[109] A.W.M. Wert, K.W. Dunn, H.J. Geuze, F.R. Maxfield, W. Stoorvogel, J. Cell Biol. 130 (1995) 821-834.

[110] A.W.M. Wert, H.J. Geuze, B. Groothuis, W. Stoorvogel, Eur. J. Cell Biol. 79 (2000) 394-399.

111] Y. Hara, K. Kizaki, Heart Lung Circ. 11 (2002) 112-116.

[112] H. Tie, B.D. Walker, C.B. Singleton, S.M. Valenzuela, J.A. Bursill, K.R. Wyse S.N. Breit, T.J. Campbell, Br. J. Pharmacol. 130 (2000) 1967-1975.

[113] S.J. Coker, A.J. Batey, I.D. Lightbown, M.E. Díaz, D.A. Eisner, Br. J. Pharmacol. 129 (2000) 323-330.

[114] S.D. Katewa, S.S. Katyare, Drug Chem. Toxicol. 28 (2005) 467-482.

[115] A. Michihara, K. Toda, T. Kubo, K. Akasaki, H. Tsuji, J. Health Sci. 54 (2008) 179-186.

[116] T. Ono-Ogata, T. Ogino, M. Nishikawa, T. Ohta, H. Yamagata, Environ. Mol. Mutagen. 39 (2002) 43-48.

[117] A.O. Talisuna, P. Bloland, U. D'Alessandro, Clin. Microbiol. Rev. 17 (2004) 235254.

[118] I.M. Hastings, Trends Parasitol. 20 (2004) 512-518.

[119] N.J. White, J. Clin. Invest. 113 (2004) 1084-1092.

[120] J.E. Hyde, Trends Parasitol. 21 (2005) 494-498.

[121] K.M.B. Ajdukiewicz, E.L.C. Ong, J. Infect. 54 (2007) 209-211.

122] J. Umbreit, Am. J. Hematol. 82 (2007) 134-144.

[123] S. Haymond, R. Cariappa, C.S. Eby, M.G. Scott, Clin. Chem. 51 (2005) 434-444

[124] P. Srivastava, S. Singh, G.K. Jain, S.K. Puri, V.C. Pandey, Ecotoxicol. Environ. Saf 45 (2000) 236-239.

125] L.K. Basco, J. Bickii, P. Ringwald, Ann. Trop. Med. Parasitol. 93 (1999) 179-182.

[126] E. Beutler, Blood 14 (1959) 103-139.

[127] R. Weed, J. Clin. Invest. 40 (1961) 140-143.

[128] R. Weed, J. Eber, A. Rothstein, J. Clin. Invest. 40 (1961) 130-139.

[129] J.N. George, R.L. O’Brien, S. Pollack, H. William, J. Clin. Invest. 45 (1966) 1280 1289.

130] I.B. Bassat, K.G. Bensch, S.L. Schrier, J. Clin. Invest. 51 (1972) 1833-1844

[131] Z.S. Bowman, J.D. Morrow, D.J. Jollow, D.C. McMillan, J. Pharmacol. Exp. Ther 314 (2005) 838-845

[132] W.R.J. Taylor, N.J. White, Drug Saf. 27 (2004) 25-61

[133] B.T. Cuong, V.Q. Binh, B. Dai, D.N. Duy, C.M. Lovell, K.H. Rieckmann, M.D. Edstein, Br. J. Clin. Pharmacol. 61 (2006) 682-689.

[134] D. Schlossberg, Ann. Intern. Med. 92 (1980) 435.

[135] J.K. Baird, D.J. Fryauff, S.L. Hoffman, Clin. Infect. Dis. 37 (2003) 1659-1667.

[136] S.W. Bass, M.A. Ramirez, D.M. Aviado, Toxicol. Appl. Pharmacol. 21 (1972) 464-481.

[137] N.J. White, Lancet Infect. Dis. 7 (2007) 549-558.

138] H. Frischer, R.L. Mellovitz, T. Ahmad, M.V. Nora, J. Lab. Clin. Med. 117 (1991) 468-476.

[139] A.M. Clark, C.D. Hufford, J.D. McChesney, Antimicrob. Agents Chemother. 19 (1981) 337-341.

[140] C.D. Hufford, A.M. Clark, I.N. Quinones, J.K. Baker, J.D. McChesney, J. Pharm. Sci. 72 (1983) 92-94

[141] G.W. Mihaly, S.A. Ward, G. Edwards, M. L'E Orme, A.M. Breckenridge, Br. J Clin. Pharmacol. 17 (1984) 441-446.

[142] A. Brossi, P. Millet, I. Landau, M.E. Bembenek, C.W. Abell, FEBS Lett. 214 (1987) 291-294.

[143] L. Constantino, P. Paixão, R. Moreira, M.J. Portela, V.E. Rosário, J. Iley, Exp. Toxicol. Pathol. 51 (1999) 299-303.

[144] Y.R. Kim, H.J. Kuh, M.Y. Kim, Y.S. Kim, W.C. Chung, S. Kim, M.W. Kang, Arch. Pharm. Res. 27 (2004) 576-580.

[145] A.M. Clark, J.D. McChesney, J.K. Baker, J. Pharm. Sci. 73 (1983) 502-506.

[146] Z.S. Bowman, J.E. Oatis, J.L. Whelan, D.J. Jollow, D.C. McMillan, J. Pharmacol Exp. Ther. 309 (2004) 79-85.

[147] Z.S. Bowman, D.J. Jollow, D.C. McMillan, J. Pharmacol. Exp. Ther. 315 (2005) 980-986.

[148] J. Vásquez-Vivar, O. Augusto, Biochem. Pharmacol. 47 (1994) 309-316.

[149] K.A. Fletcher, P.F. Barton, J.A. Kelly, Biochem. Pharmacol. 37 (1988) 2683 2690.

[150] J. Vásquez-Vivar, O. Augusto, J. Biol. Chem. 267 (1992) 6848-6854.

[151] A. Strother, R. Allahyari, J. Buchholz, I.M. Fraser, B.E. Tilton, Drug Metab. Dispos. 12 (1984) 35-44.

[152] C.M. Link, A.D. Theoharides, J.C. Anders, H. Chung, C.J. Canfield, Toxicol. Appl Pharmacol. 81 (1985) 192-202.

[153] A. Strother, I.M. Fraser, R. Allaahyyari, B.E. Tilton, Bull. World Health Organ. 59 (1981) 413-425. 
[154] L.J.C. Bolchoz, R.A. Budinsky, D.C. Mcmillan, D.J. Jollow, J. Pharmacol. Exp. Ther. 297 (2001) 509-515.

[155] L.J.C. Bolchoz, A.K. Gelasco, D.J. Jollow, D.C. McMillan, J. Pharmacol. Exp. Ther 303 (2002) 1121-1129.

[156] A.M. Clark, C.D. Hufford, R.K. Puri, J.D. McChesney, Appl. Environ. Microbiol. 47 (1984) 540-543.

[157] C.D. Hufford, A.M. Clark, J.D. McChesney, J. Org. Chem. 49 (1984) 2822-2823.

[158] V.K. Dua, S.N. Sinha, S. Biswas, N. Valecha, S.K. Puri, V.P. Sharma, Bioorg. Med Chem. Lett. 12 (2002) 3587-3589.

[159] C.D. Hufford, J.K. Baker, J.D. McChesney, A.M. Clark, Antimicrob. Agents Chemother. 30 (1986) 234-237.

[160] R.G. Ridley, A. Hudson, Exp. Opin. Ther. Pat. 8 (1998) 121-136.

[161] R.V. Shetty, C.D. Blanton, J. Med. Chem. 21 (1978) 995-998.

[162] F.I. Carrol, B.D. Berrang, C.P. Linn, J. Med. Chem. 23 (1980) 581-584.

[163] L.H. Schidt, Antimicrob. Agents Chemother. 24 (1983) 615-652.

[164] M. Jain, S. Vangapandu, S. Sachdeva, R. Jain, Bioorg. Med. Chem. 12 (2004) 1003-1010.

[165] M. Jain, S. Vangapandu, S. Sachdeva, S. Singh, P.P. Singh, G.B. Jena, K. Tikoo, P. Ramarao, C.L. Kaul, R. Jain, J. Med. Chem. 47 (2004) 285-287.

[166] N.T. Huy, K. Mizunuma, K. Kaur, N.T.T. Nhien, M. Jain, D.T. Uyen, S. Harada, R. Jain, K. Kamei, Antimicrob. Agents Chemother. 51 (2007) 2842-2847.

[167] M. Jain, S.I. Khan, B.L. Tekwani, M.R. Jacob, S. Singh, P.P. Singh, R. Jain, Bioorg. Med. Chem. 13 (2005) 4458-4466.

[168] E.A. Nodiff, K. Tanabe, E.H. Chen, A.J. Saggiomo, J. Med. Chem. 25 (1982) 1097-1101

[169] M.P. LaMontagne, A. Markovac, J.R. Menke, J. Med. Chem. 20 (1977) 11221127.

[170] F.I. Carroll, B. Berrang, C.P. Linn, J. Med. Chem. 21 (1978) 326-330.

[171] F.I. Carroll, B. Berrang, C.P. Linn, C.E. Twine, J. Med. Chem. 22 (1979) 694-699

[172] M.P. LaMontagne, P. Blumbergs, R.E. Strube, J. Med. Chem. 25 (1982) 10941097.

[173] F.I. Carroll, B.D. Berrang, C.P. Linn, J. Med. Chem. 29 (1986) 1796-1798.

[174] E.C. Chen, K. Tanabe, A.J. Saggiomo, E.A. Nodiff, J. Med. Chem. 30 (1987) 1193 1199.

[175] M.P. LaMontagne, P. Blumbergs, D.C. Smith, J. Med. Chem. 32 (1989) 1728 1732.

[176] S. Vangapandu, S. Sachdeva, M. Jain, S. Singh, P.P. Singh, C.L. Kaul, R. Jain, Bioorg. Med. Chem. 11 (2003) 4557-4568.

[177] S. Vangapandu, S. Sachdeva, M. Jain, S. Singh, P.P. Singh, C.L. Kaul, R. Jain, Bioorg. Med. Chem. 12 (2004) 239-247.

[178] E.H. Chen, A.J. Saggiomo, K. Tanabe, B.L. Verma, E.A. Nodiff, J. Med. Chem. 20 (1977) 1107-1109.

[179] R. Allahyari, A. Strother, I.M. Fraser, A.J. Anthony, J. Med. Chem. 27 (1984) 407-410.

[180] K. Kirk, Physiol. Rev. 81 (2001) 495-537.

[181] J. Hofsteenge, A. Capuano, R. Altszuler, S. Moore, J. Med. Chem. 29 (1986) 1765-1769.

[182] A. Philip, J.A. Kepler, B.H. Johnson, F.I. Carrol, J. Med. Chem. 31 (1988) 870874.

[183] H. Bundgaard, J. Moss, J. Pharm. Sci. 78 (1989) 122-126.

[184] R. Borissova, B. Lammek, P. Stjärnkvist, I. Sjöholm, J. Pharm. Sci. 84 (1995) 249-255.

[185] R. Borissova, P. Stjärnkvist, M.O. Karlsson, I. Sjäholm, J. Pharm. Sci. 84 (1995) 256-262.

[186] M.C. Chung, M.F. Gonçalves, W. Colli, E.I. Ferreira, M.T.M. Miranda, J. Pharm. Sci. 86 (1997) 1127-1131.

[187] M.J. Portela, R. Moreira, E. Valente, L. Constantino, J. Iley, J. Pinto, R. Rosa, P. Cravo, V.E. Rosário, Pharm. Res. 16 (1999) 949-955.

[188] P. Gomes, M.J. Araújo, M. Rodrigues, N. Vale, Z. Azevedo, J. Iley, P. Chambel, J. Morais, R. Moreira, Tetrahedron 60 (2004) 5551-5562.

[189] R. Ferraz, J.R.B. Gomes, E. Oliveira, R. Moreira, P. Gomes, J. Org. Chem. 72 (2007) 4189-4197.

[190] M.J. Araújo, J. Bom, R. Capela, C. Casimiro, P. Chambel, P. Gomes, J. Iley, F. Lopes, J. Morais, R. Moreira, E. Oliveira, V. Rosário, N. Vale, J. Med. Chem. 48 (2005) 888-892.

[191] P. Chambel, R. Capela, F. Lopes, J. Iley, J. Morais, L. Gouveia, J.R.B. Gomes, P. Gomes, R. Moreira, Tetrahedron 62 (2006) 9883-9891.

[192] N. Vale, R. Moreira, P. Gomes, Química 99 (2005) 57-69.

[193] N. Vale, M.S. Collins, J. Gut, R. Ferraz, P.J. Rosenthal, M.T. Cushion, R. Moreira, P. Gomes, Bioorg. Med. Chem. Lett. 18 (2008) 485-488.

[194] N. Vale, J. Matos, J. Gut, F. Nogueira, V. Rosário, P.J. Rosenthal, R. Moreira, P. Gomes, Bioorg. Med. Chem. Lett. 18 (2008) 4150-4153.

[195] S. Romeo, M. Dell'Agli, S. Parapini, L. Rizzi, G. Galli, M. Mondani, A. Sparatore, D. Taramelli, E. Bosisio, Bioorg. Med. Chem. Lett. 14 (2004) 2931-2934.

[196] M.A. La-Scalea, C.M.S. Menezes, G.C. Matsutami, M.C. Polli, S.H.P. Serrano, E.I. Ferreira, Electrochim. Acta 51 (2006) 5103-5111.

[197] G. Zzimbeg, B. Zorc, M. Kralj, K. Ester, K. Pavelic, G. Andrei, R. Snoeck, J. Balzarini, E. De Clercq, M. Mintan, Eur. J. Med. Chem. 43 (2008) 1180-1187.

[198] S. Zhu, Q. Zhang, C. Gudise, L. Meng, L. Wei, E. Smith, Y. Kong, Bioorg. Med. Chem. Lett. 17 (2007) 6101-6106.
[199] R.P. Tripathi, R.C. Mishra, N. Dwivedi, N. Tewari, S.S. Verma, Curr. Med. Chem. 12 (2005) 2643-2659.

[200] G.A. Biagini, P.M. O’Neill, P.G. Bray, S. Ward, Curr. Opin. Pharmacol. 5 (2005) $1-6$.

[201] B. Avula, L.M. Tripathi, S.I. Khan, B.L. Tekwani, D. Nanayakkara, W. Gul, M.A. ElSolhly, I.A. Khan, Chromatographia 64 (2006) 429-434.

[202] A.K. Dutta, B.A. Avery, C.M. Wyandt, J. Chromatogr. A 1110 (2006) 35-45

[203] P. Srivastava, S.K. Sahni, L.M. Tripathi, S.K. Puri, G.P. Dutta, V.C. Pandey, Biochem. Pharmacol. 43 (1992) 904-907.

[204] R. Pratap, A.P. Bhaduri, H.P. Thapliyal, S.K. Puri, G.P. Dutta, A.K. Dwlvedl, S. Singh, P. Srivastava, V.C. Pandey, S. Srivastava, S.K. Singh, R.C. Gupta, J.S. Srivastava, O.P. Asthana, EP 1055427 B1, 2004.

[205] N. Valecha, T. Adak, A.K. Bagga, O.P. Asthana, J.S. Srivastava, H. Joshi, V.P. Sharma, Curr. Sci. India 80 (2001) 561-563.

[206] M. Nitin, M. Rajanikanth, J. Lal, K.P. Madhusudanan, R.C. Gupta, J. Chromatogr. B 793 (2003) 253-263.

[207] V.C. Pandey, S.K. Puri, S.K. Sahni, P. Srivastava, G.P. Dutta, Pharmacol. Res. 22 (1990) 701-707.

[208] J. Lal, N. Mehrotra, R.C. Gupta, J. Pharm. Biomed. Anal. 32 (2003) 141-150.

[209] S.K. Puri, G.P. Dutta, Exp. Parasitol. 111 (2005) 8-13.

[210] S.K. Puri, R. Srivastava, V.C. Pandey, N. Sethi, G.P. Dutta, Am. J. Trop. Med. Hyg. 41 (1989) 638-642.

[211] G.P. Dutta, S.K. Puri, A.P. Bhaduri, M. Seth, Am. J. Trop. Med. Hyg. 41 (1989) 635-637.

[212] J.K. Paliwal, R.C. Gupta, P.K. Grover, J. Chromatogr. 616 (1993) 155-160.

[213] J.K. Paliwal, R.C. Gupta, J. Pharm. Biomed. Anal. 17 (1998) 775-783.

[214] N. Mehrotra, J. Lal, S.K. Puri, K.P. Madhusudanan, R.C. Gupta, Biopharm. Drug Dispos. 28 (2007) 209-227.

[215] R.P. Brueckner, K.C. Lasseter, E.T. Lin, B.G. Schuster, Am. J. Trop. Med. Hyg. 58 (1998) 645-649.

[216] P. Nasveld, S. Kitchener, Trans. R. Soc. Trop. Med. Hyg. 99 (2005) 2-5.

[217] R.P. Brueckner, T. Coster, D.L. Wesche, M. Shmuklarsky, B.G. Schuster, Antimicrob. Agents Chemother. 42 (1998) 1293-1294.

[218] J.L. Vennerstrom, E.O. Nuzum, R.E. Miller, A. Dorn, L. Gerena, P.A. Dande, W.Y. Ellis, R.G. Ridley, W.K. Milhous, Antimicrob. Agents Chemother. 43 (1999) 598-602.

[219] B. Lell, J.F. Faucher, M.A. Missinou, S. Borrmann, O. Dangelmaier, J. Horton, P.G. Kremsner, Lancet 355 (2000) 2041-2045.

[220] G.D. Shanks, A.J. Oloo, G.M. Aleman, C. Ohrt, F.W. Klotz, D. Braitman, J. Horton, R. Brueckner, Clin. Infect. Dis. 33 (2001) 1968-1974.

[221] M. Ramharter, H. Noedl, K. Thimasarn, G. Wiedermann, G. Wernsdorfer, W.H. Wernsdorfer, Am. J. Trop. Med. Hyg. 67 (2002) 39-43.

[222] B.R. Hale, O. Agyei, D.J. Fryauff, K.A. Koram, M. Adjuik, A.R. Oduro, W.R. Prescott, J.K. Baird, F. Nkrumah, T.L. Ritchie, E.D. Franke, F.N. Binka, Clin. Infect. Dis. 36 (2003) 541-549.

[223] D.S. Walsh, C. Eamsila, T. Sasiprapha, S. Sangkharomya, P. Khaewsathien, P. Supakalin, D.B. Tang, P. Jarasrumgsichol, C. Cherdchu, M.D. Edstein, K.H. Rieckmann, T.G. Brewer, J. Infect. Dis. 190 (2004) 1456-1463.

[224] M.D. Edstein, D.A. Kocisko, T.G. Brewer, D.S. Walsh, C. Eamsila, Br. J. Clin. Pharmacol. 52 (2001) 663-670.

[225] P. Nasved, S. Kitchener, M. Edstein, K. Rieckmann, Trans. R. Soc. Trop. Med. Hyg. 96 (2002) 683-684.

[226] S. Kitchener, P. Nasveld, M.D. Edstein, Am. J. Trop. Med. Hyg. 76 (2007) 494496.

[227] B. Pradines, M.M. Manfoumbi, A. Tall, C. Sokhna, J.L. Koeck, T. Fusai, J. Mosnier, E. Czarnecki, A. Spiegel, J.F. Trape, M. Kombila, C. Rogier, Antimicrob. Agents Chemother. 50 (2006) 3225-3226.

[228] B.S. Levine, E.M. Furedi-Machacek, A.P. Brown, M.J. Tomlinson, Drug Dev. Res. 40 (1997) 75-87.

[229] M.K. Wasunna, J.R. Rachid, J. Mbui, G. Kirigi, D. Kinoti, H. Lodenyo, J.M. Felton, A.J. Sabin, M.J. Albert, J. Horton, Am. J. Trop. Med. Hyg. 73 (2005) 871-876.

[230] T.K. Jha, S. Sundar, C.P. Thakur, J.M. Felton, A.J. Sabin, J. Horton, Am. J. Trop. Med. Hyg. 73 (2005) 1005-1011.

[231] J.R. Luque-Ortega, J.M. Saugar, C. Chiva, D. Andreu, L. Rivas, Biochem. J. 375 (2003) 221-230.

[232] M.L. Mangoni, J.M. Saugar, M. Dellisanti, D. Barra, M. Simmaco, L. Rivas, J. Biol. Chem. 280 (2005) 984-990.

[233] Luque-Ortega, W. Van't Hof, E.C.I. Veerman, J.M. Saugar, L. Rivas, FASEB J 22 (2008) 1817-1828.

[234] R. Allison, F. Hahn, Antimicrob. Agents Chemother. 11 (1977) 251-257.

[235] J.K. Baird, M.D. Lacy, H. Basri, M.J. Barcus, J.D. Maguire, M.J. Bangs, R. Gramzinski, P. Sismadi, Krisim, J. Ling, I. Wiady, M. Kusumaningsih, T.R. Jones, D.J. Fryauff, S.L. Hoffman, United States Naval Medical Research Unit 2 Clinical Trials Team, Clin. Infect. Dis. 33 (2001) 1990-1997.

[236] N.J. Beeching, D.G. Lalloo, B.A. Bannister, J. Infect. 55 (2007) 282.

[237] L. McRobert, C.J. Taylor, W. Deng, Q.L. Fivelman, R.M. Cummings, S.D. Polley, O. Billker, D.A. Baker, PLoS Biol. 6 (2008) e139.doi:10.1371/journal.pbio. 0060139.

[238] M.J. Dasconde, M.G.B. Drew, P.G. Evans, F.M.D. Ismail, Front. Drug Des. Discov. 3 (2007) 559-609. 